\title{
Diastereoselective reduction of cyclic bioactive Mannich ketones
}

\author{
Tamás Lóránd, ${ }^{\mathrm{a} *}$ Erzsébet Ősz, ${ }^{\mathrm{a}}$ Gyula Kispál, ${ }^{\mathrm{a}}$ Gergely Nagy, ${ }^{\mathrm{b}}$ Edgar Weckert, ${ }^{\mathrm{c}}$ Daniel \\ Luebbert, ${ }^{\mathrm{c}}$ Alke Meents, ${ }^{\mathrm{c}}$ Béla Kocsis, ${ }^{\mathrm{d}}$ and László Prókai ${ }^{\mathrm{e}}$ \\ ${ }^{a}$ Department of Biochemistry and Medical Chemistry, Faculty of Medicine, University Pécs, $H$ - \\ 7601 Pécs, P.O.Box 99, Hungary \\ ${ }^{b}$ Department of Immunology and Biotechnology, Faculty of Medicine, University Pécs, H-7601 \\ Pécs, P.O.Box 99, Hungary \\ ' HASYLAB at DESY Notkestr. 85, D-22607 Hamburg, Germany', \\ ${ }^{d}$ Department of Medical Microbiology and Immunology, Faculty of Medicine, University Pécs, \\ H-7601 Pécs, P.O.Box 99, Hungary \\ ${ }^{e}$ Department of Medicinal Chemistry, College of Pharmacy, University of Florida, Gainesville, \\ FL 32610-0485 \\ E-mail: tamas.lorand@aok.pte.hu
}

\section{Dedicated to Professor Sándor Antus on his $60^{\text {th }}$ birthday}

(received 18 Jul 03; accepted 05 Nov 03; published on the web 17 Nov 03)

\begin{abstract}
The reduction of cyclic Mannich ketones having antibacterial activity showed poor stereoselectivity with $\mathrm{L}$-Selectride ${ }^{\circledR}$, sodium trimethoxyborohydride and diisobutylaluminium hydride, while lithium aluminium hydride and, in particular, sodium borohydride often yielded a single stereoisomer. The size of the ring strongly influenced the stereocomposition of the reaction mixtures. An increased preference for the trans isomer was attributed to a weak intramolecular hydrogen bond between the $\mathrm{OH}$ and the $\mathrm{N}$, as demonstrated by X-ray crystallography. After reduction, the antibacterial activity of the product decreased dramatically ("S-form") but was not completely abolished in deep rough mutants of Gram-negative bacteria.
\end{abstract}

Keywords: Reduction, molecular modelling, X-ray crystallography, NMR spectroscopy, deep rough $(\mathrm{Re})$ mutants.

\section{Introduction}

Studies on the mechanism of action for biologically active compounds often have been complex endeavours, with synthetic organic and medicinal chemistry often playing a crucial role in providing invaluable insight into the intricate and previously unrecognised details. Previously we reported the synthesis of some Mannich ketones of 2-arylidenecycloalkanones ${ }^{1}$ 1-9 (Scheme 1). 
Similar derivatives of fused bicyclic ketones such as 1-indanones and 1-tetralones 10-11 also were prepared ${ }^{2}$ (Scheme 1). The majority of these compounds showed antibacterial activity both against standard Gram-positive (Staphylococcus saprophyticus, S. aureus, Micrococcus luteus, Bacillus subtilis) and a Gram-negative strain such as Escherichia coli. Such compounds have been considered thiol alkylators because under physiological conditions they give reactive methylene ketones (by 1,2-elimination) that can undergo addition reactions with thiol enzymes. ${ }^{3}$

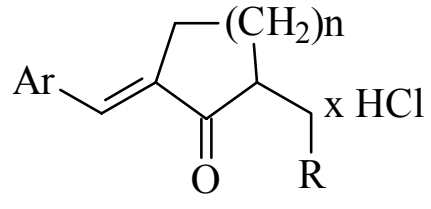

1-9

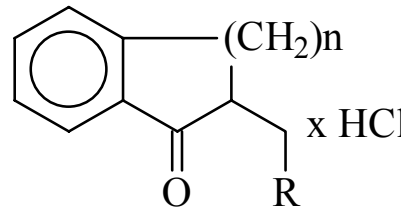

10-11

\begin{tabular}{llll}
\hline Comp. & $\mathrm{n}$ & $\mathrm{R}$ & $\mathrm{Ar}$ \\
\hline $\mathbf{1}$ & 1 & Pip & $\mathrm{Ph}$ \\
$\mathbf{2}$ & 1 & Pip & $4^{\prime}-\mathrm{OCH}_{3}-\mathrm{C}_{6} \mathrm{H}_{4}$ \\
$\mathbf{3}$ & 2 & Mor & $\mathrm{Ph}$ \\
$\mathbf{4}$ & 2 & $\mathrm{Pyr}$ & $\mathrm{Ph}$ \\
$\mathbf{5}$ & 2 & $4-\mathrm{Pip}$ & $\mathrm{Ph}$ \\
$\mathbf{6}$ & 3 & Mor & $\mathrm{Ph}$ \\
$\mathbf{7}$ & 3 & Pip & $\mathrm{Ph}$ \\
$\mathbf{8}$ & 4 & Mor & $\mathrm{Ph}$ \\
$\mathbf{9}$ & 4 & Pip & $\mathrm{Ph}$ \\
$\mathbf{1 0}$ & 1 & Mor & $\mathrm{Ph}$ \\
$\mathbf{1 1}$ & 2 & Pyr & $\mathrm{Ph}$ \\
\hline
\end{tabular}

Pip: 1-Piperidinyl;

Mor: 4-Morpholinyl;

Pyr: 1-Pyrrolidinyl;

4-Pip: 4-methyl-1-piperidyl.

Scheme 1

Our previous examinations suggested however that the thiol depletion cannot be the only reason for the antibacterial activity. ${ }^{1,2}$ We showed that some compounds were highly active against bacteria, but caused no thiol depletion, others were not active although the free thiol pool decreased significantly when the compounds were administered at the minimum inhibitory concentration (MIC).

In order to investigate the importance of thiol reactivity in the mechanism of action, we prepared the corresponding amino alcohols from the Mannich ketones mentioned above. Unlike the Mannich ketones, the amino alcohols cannot yield very reactive methylene ketones.

First, we wanted to investigate the stereoselectivity of the reduction using different complex metal hydrides with organic groups. Sodium borohydride is a generally more selective 
agent for preparing allylic alcohols than lithium aluminium hydride. ${ }^{4}$ The hydride reduction of $\alpha, \beta$-unsaturated Mannich ketones may, however, afford 1,2- or 1,4-addition products. We also aimed at studying the stereocomposition of reduction products depending on the structure of the substrate (size of the ketone ring and the nature of the amine substituent). The starting materials for the reductions were selected as both effective antibacterial agents and less effective ones ( $c f$. 1, 3, 10 and 6-9). We also planned to analyse the effect of reduction on the antibacterial activity of our Mannich ketones. The antibacterial activity and the thiol depletion were examined in two E. coli strains, in an "S" type (ATCC 25292) and in a Re mutant one which has a defective cell wall biosynthesis. The Re mutants are therefore more permeable to some externally added chemicals.

\section{Results and Discussion}

In order to investigate the influence of the reducing agent on the stereocomposition, we explored the reduction of $\mathbf{3}$ with different complex metal hydrides. These reactions started from the Mannich base liberated from the corresponding hydrochloride $\mathbf{3}$ under mild conditions (Scheme 2 ). The complex hydrides applied for the reduction of $\mathbf{3}$ can be divided into two groups. The first one $\left(L\right.$-Selectride ${ }^{\circledR}$, sodium trimethoxyborohydride, diisobutylaluminium hydride) represents reducing agents showing poor stereoselectivity, while the hydrides of the other group, such as lithium aluminium hydride, produced stereoselective reductions affording the trans isomer as a major isomer. In particular, reduction performed with sodium borohydride proved to be rather stereoselective, yielding mainly one stereoisomer (Scheme 2).
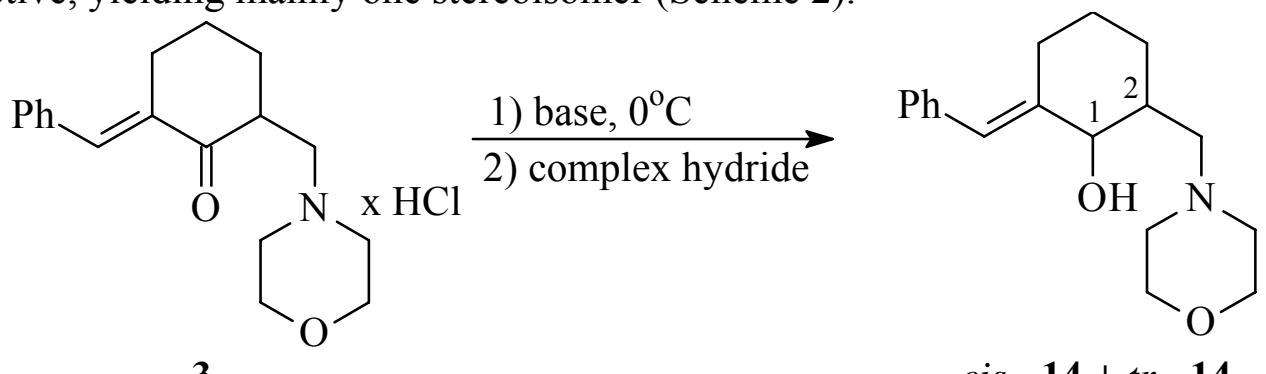

\begin{tabular}{|c|c|}
\hline Reagent & cis/trans Ratio \\
\hline $\begin{array}{c}\text { L-Selectride }{ }^{\circledR} \text { (Litium tri-sec- } \\
\text { butylborohydride) }\end{array}$ & $8 / 7$ \\
\hline $\mathrm{Na}\left[\mathrm{B}\left(\mathrm{OCH}_{3}\right)_{3} \mathrm{H}\right]$ & $1 / 1$ \\
\hline DIBAH (diisobutylaluminium hydride) & $1 / 1$ \\
\hline $\mathrm{LiAlH}_{4}$ & $2 / 7$ \\
\hline $\mathrm{NaBH}_{4}$ & $1 / 6$ \\
\hline
\end{tabular}

\section{Scheme 2}

We hypothesized that the relative thermodynamic stability of the respective hydride adducts (cis-14a-e and trans-14a-e) should explain the observed selectivity of the metal-hydride 
reduction of the Mannich base chosen. To prove this hypothesis, semi-empirical (PM5) quantum chemical calculations were performed to obtain heats of formation $\left(\Delta \mathrm{H}_{\mathrm{f}}{ }^{\circ}\right)$ for the hydride adducts (Scheme 3). As shown in Table 1, the relative stabilities of the isomeric cis-14a-e and trans14a-e (expressed as $\Delta \mathrm{H}_{\mathrm{f}}^{\circ}$ cis $-\Delta \mathrm{H}_{\mathrm{f}}^{\circ}$ trans) correlated well with the observed stereocomposition of the end product 14, although a bias to yield trans-14 during the reduction also was apparent.

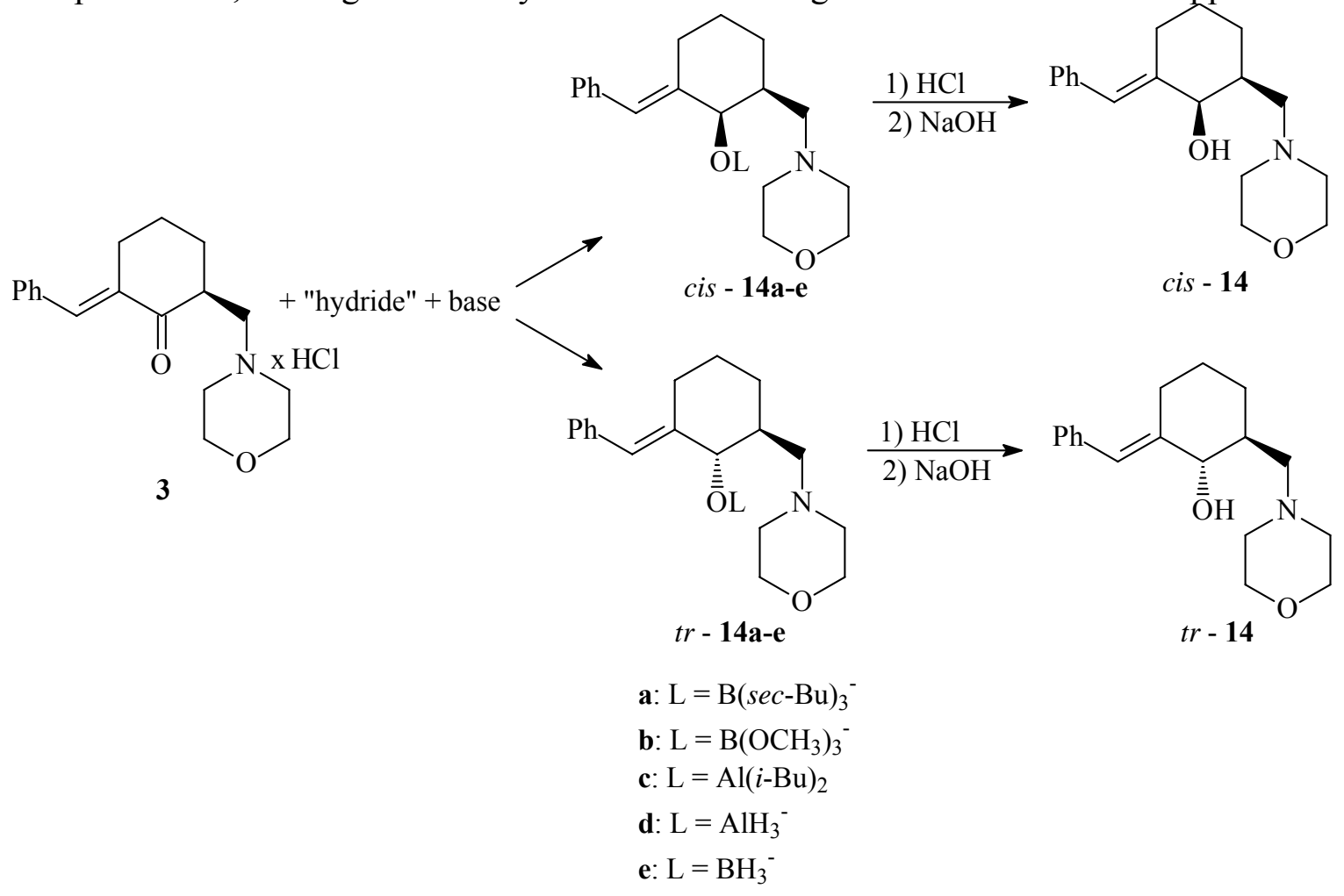

\section{Scheme 3}

Table 1. Calculated heats of formation ( $\mathrm{kcal} / \mathrm{mol}$; by PM5 semi-empirical quantum chemical method) of the intermediates (14a-14e)

\begin{tabular}{cccc}
\hline Compound & $\Delta \mathrm{H}_{\mathrm{f}}{ }^{\circ}(\mathrm{kcal} / \mathrm{mol})$ & $\Delta\left(\Delta \mathrm{H}_{\mathrm{f}}^{\circ} \text { cis-trans }\right)^{\mathrm{a}}(\mathrm{kcal} / \mathrm{mol})$ & $\begin{array}{c}\text { trans/cis Ratio in the end- } \\
\text { product }(\mathbf{1 4})\end{array}$ \\
\hline cis-14a & -189.2 & -3.4 & 0.9 \\
trans-14a & -185.8 & -1.2 & 1.0 \\
$\quad$ cis-14b & -347.0 & & \\
trans-14b & -345.8 & -0.1 & 1.0 \\
$\quad$ cis-14c & -143.7 & & 3.5 \\
trans-14c & -143.6 & 0.7 & \\
cis-14d & -119.4 & & 6.1 \\
trans-14d & -120.1 & 2 & \\
cis-14e & -118.5 & & \\
trans-14e & -120.5 & & \\
\hline
\end{tabular}

${ }^{\mathrm{a}} \Delta \mathrm{H}_{\mathrm{f}}^{\circ}$ cis $-\Delta \mathrm{H}_{\mathrm{f}}^{\circ}$ transans 
Because of its propensity to produce the highest stereoselectivity based on the preliminary experiments, sodium borohydride was chosen as the reducing agent to study the influence of the substrate on the stereocomposition of the reaction mixture. The reductions were performed in methanolic solutions at room temperature. In all of the starting unsaturated Mannich ketones the configuration was $E$ around the $\mathrm{C}=\mathrm{C}$ bond. From the hydrochlorides of the Mannich ketones (1-9 and 10-11) the bases were liberated with equivalent $\mathrm{NaOH}$ at $0{ }^{\circ} \mathrm{C}$ and they were treated with $\mathrm{NaBH}_{4}$ (Schemes 4-5).

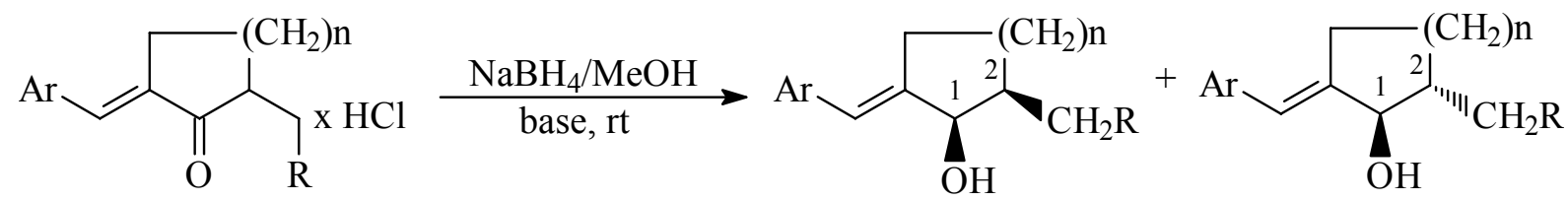

\begin{tabular}{|c|c|c|c|c|c|c|c|}
\hline \multicolumn{4}{|c|}{$1-9$} & \multicolumn{4}{|c|}{$12-20$} \\
\hline \multirow[t]{2}{*}{ Comp. } & \multirow[t]{2}{*}{$\mathrm{n}$} & \multirow[t]{2}{*}{$\mathrm{R}$} & \multirow[t]{2}{*}{$\mathrm{Ar}$} & \multirow[t]{2}{*}{ Conf. } & \multirow[t]{2}{*}{ Cis/trans ratio } & \multicolumn{2}{|c|}{ Yield $(\%)$} \\
\hline & & & & & & cis & trans \\
\hline trans-12 & 1 & Pip & $\mathrm{Ph}$ & trans & $0: 100$ & - & 87 \\
\hline trans -13 & 1 & Pip & $4-\mathrm{OCH}_{3}-\mathrm{C}_{6} \mathrm{H}_{4}$ & trans & $0: 100$ & - & 67 \\
\hline cis-14 & 2 & Mor & $\mathrm{Ph}$ & cis & $14: 86$ & 12 & - \\
\hline trans-14 & 2 & Mor & $\mathrm{Ph}$ & trans & $14: 86$ & - & 77 \\
\hline $\operatorname{trans}-15^{*}$ & 2 & Pyr & $\mathrm{Ph}$ & trans & $0: 100$ & - & 85 \\
\hline trans-16 & 2 & 4-Pip & $\mathrm{Ph}$ & trans & $0: 100$ & - & 76 \\
\hline cis-17 & 3 & Mor & $\mathrm{Ph}$ & cis & $96: 4$ & 86 & - \\
\hline $\operatorname{trans}-17^{*}$ & 3 & Mor & $\mathrm{Ph}$ & trans & $96: 4$ & - & - \\
\hline cis-18 & 3 & Pip & $\mathrm{Ph}$ & cis & $65: 35$ & 47 & - \\
\hline trans-18 & 3 & Pip & $\mathrm{Ph}$ & trans & $65: 35$ & - & 25 \\
\hline cis-19 & 4 & Mor & $\mathrm{Ph}$ & cis & $100: 0$ & 90 & - \\
\hline cis-20 & 4 & Pip & $\mathrm{Ph}$ & cis & $100: 0$ & 93 & - \\
\hline
\end{tabular}

*Not isolated in pure state

\section{Scheme 4}<smiles>[R]CC1Cc2ccccc2C1=O</smiles>

10 - 11

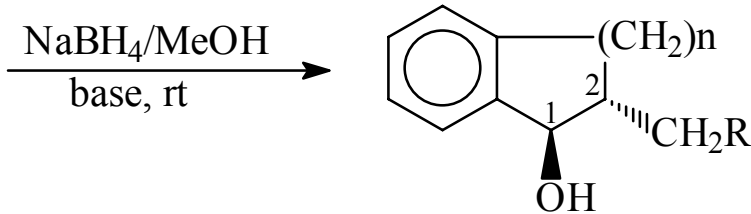

trans-21 - trans-22

\begin{tabular}{cccccc} 
Comp. & $\mathbf{n}$ & $\mathrm{R}$ & Conf. & Cis $/$ trans ratio & Yield (\%) \\
\hline $\operatorname{trans} \mathbf{- 2 1}$ & 1 & Mor & trans & $0: 100$ & 90 \\
$\operatorname{trans} \mathbf{2 2}$ & 2 & $\mathrm{Pyr}$ & trans & $0: 100$ & 79 \\
\hline
\end{tabular}

\section{Scheme 5}


The composition of the reaction mixture was monitored by ${ }^{1} \mathrm{H}$ NMR spectroscopy. The diastereoisomers were separated by column chromatography when it was possible. The conversion was always $100 \%$. The size of the ring strongly influenced the stereocomposition of the reaction mixtures giving only the trans isomers with the five membered and only the cis with the eight membered rings. Probably, the trans diastereoisomer is stabilized by the intramolecular hydrogen bond between $\mathrm{OH}$ and the nitrogen atom.

Cis and trans indicate the orientation of bonds $\mathrm{C} 1-\mathrm{H} 1$ and $\mathrm{C} 2-\mathrm{H} 2$ as well as of bonds $\mathrm{C} 1-\mathrm{H} 1$ and $\mathrm{C} 7(8)-\mathrm{H} 7(8)$ each to other in compounds 12-20 and 21-22, respectively. The structure verification of our compounds was performed by FT-IR, ${ }^{1} \mathrm{H}-\mathrm{NMR}$, and ${ }^{13} \mathrm{C}-\mathrm{NMR}$ spectroscopy (Fig. 1) ${ }^{* *}$ and, in the case of trans-14, by crystal structure analysis (Table 2 ).
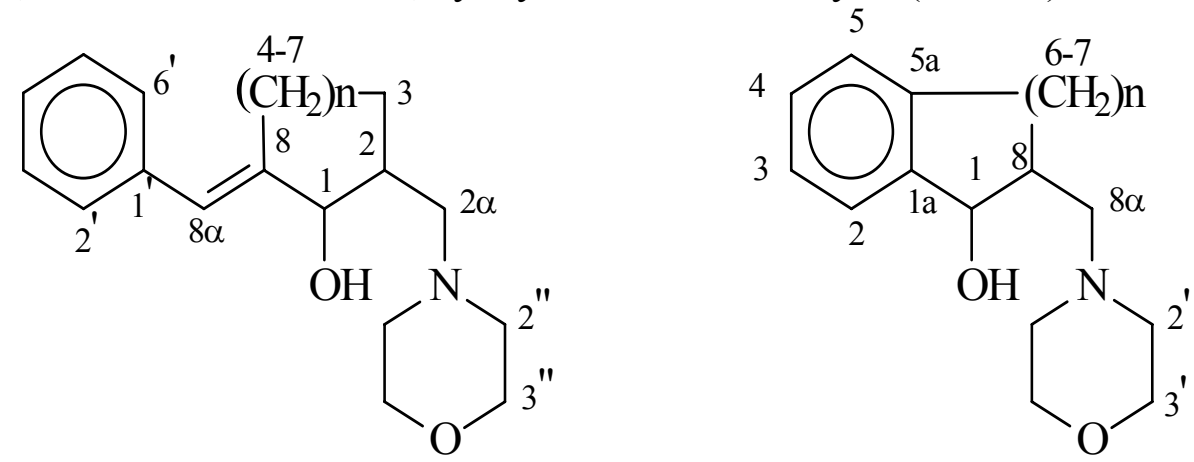

Figure 1. NMR numbering of selected compounds.

The molecule shows an intramolecular $\mathrm{H}$-bond $\mathrm{O} 2-\mathrm{H} 4 \cdots \mathrm{N} 1$ with an $\mathrm{H} 4-\mathrm{N} 1$ distance of 1.955 $\AA$ and an angle of 151. All distances and angles are within the experimental errors in the expected range. ${ }^{5}$ The $\mathrm{C} 1-\mathrm{C} 6$ as well as the hetero 6-ring are in chair conformations. Ring C1-C6 is slightly distorted from the ideal conformation due to the $\mathrm{sp}^{2}$ hybridisation of $\mathrm{C} 1$. The conformation about the $\mathrm{C} 1-\mathrm{C} 7$ double bound is $E$ (trans). The interaction between the molecules in the crystal is only of the van der Waals type.

The new compounds were screened against some standard Gram-positive and Gram-negative strains, among them some Re deep rough mutants strains (Table 3). The reduction dramatically decreased the antibacterial activity of the original Mannich ketones both against the Grampositive and -negative strains (e.g. 3 S. aureus MIC: $1.56 \mu \mathrm{g} \mathrm{mL}^{-1}$; cis-14 MIC: $>200 \mu \mathrm{g} \mathrm{mL}^{-1}$ ). ${ }^{1,2}$ However, some of the compounds (trans-13, cis-17, trans-18, trans-20) showed slight activity to Grampositive strains. With the deep mutant strains, some of the amino alcohols tested (cis-14, trans14, trans-16, cis-17, cis-19 and cis-20) showed moderate activity. The comparison of the antibacterial activity of Mannich ketones ${ }^{1-2}$ and the corresponding amino alcohols proves that the keto group is required for the biological effect in most of the compounds. The slightly increased polarity of the compounds cannot explain their diminished antibacterial activity. The decreased antibacterial effect of the amino alcohols can partly support the thiol alkylation as a mechanism

\footnotetext{
** The NMR numbering is shown on Fig. 1. displaying the morpholino derivative as an example. The numbering of the unsaturated and fused compounds differs from the IUPAC numbering given in the Experimental because of the better comparison of the data.
} 
of action. However, the existing but weak antibacterial effect on M. luteus (trans-13, cis-20), S. saprophyticus (cis-20) and Re strains probably can be based on another mechanism of action.

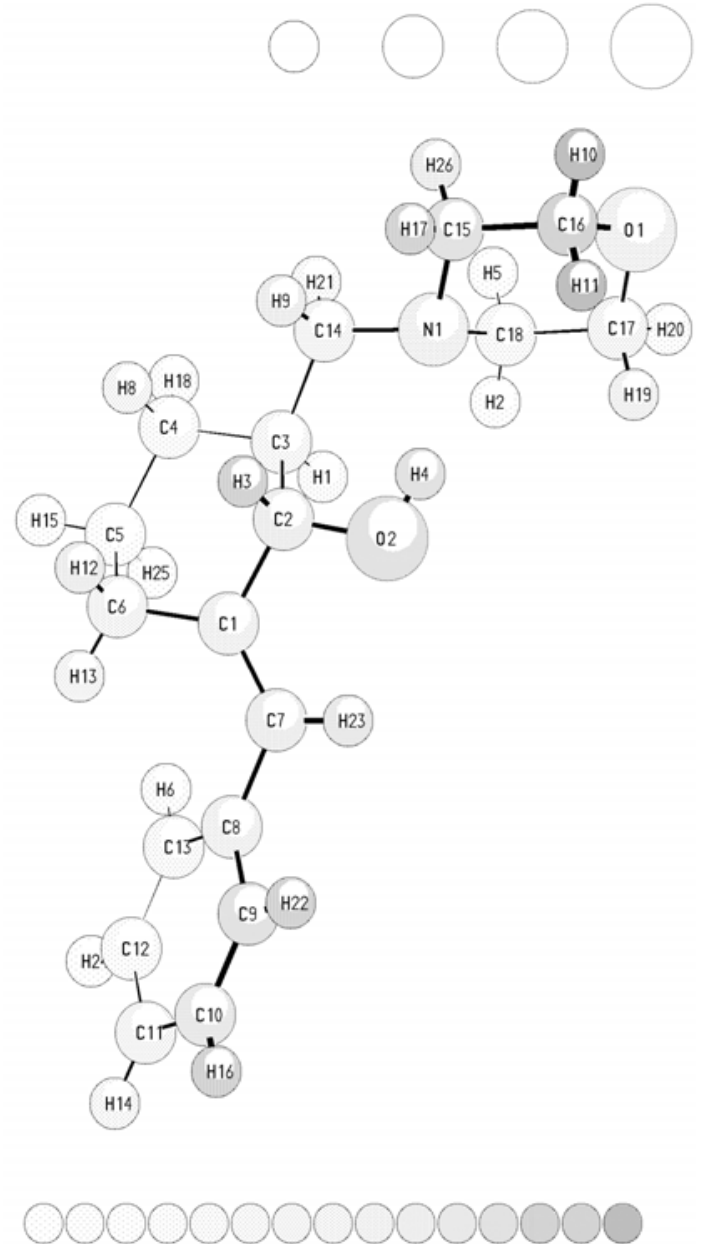

Figure 2. Projection of trans-14 with anisotropic displacement ellipsoids (50\% probability) for non-H atoms and an arbitrary small displacement parameter for $\mathrm{H}$-atoms. ${ }^{13}$

A close relationship can be deduced from our data between the permeability and the antibacterial activity of our compounds. We determined the MIC values for " $\mathrm{S}$ " form E. coli ATCC 25292 and "Re" form E. coli ReD31m4, Salmonella minnesota Re595, Shigella sonnei Re4350. These Re deep rough mutants have modified outer membranes that are more permeable for some chemicals than the " $\mathrm{S}$ " form $E$. coli that has a complete outer membrane. ${ }^{6-8}$ Thus cis14, trans-14, cis-17, cis-19 and cis-20, that are only mildly active or non active to " $\mathrm{S}$ " form, can kill the Re mutant Gram-negative bacteria. 
Table 2. Bond lengths $(\AA)$ and angles $\left(^{\circ}\right)$ for trans-14

\begin{tabular}{|c|c|c|c|}
\hline$C(1)-C(7)$ & $1.3420(6)$ & $\mathrm{O}(2)-\mathrm{C}(2)-\mathrm{C}(3)$ & $111.83(3)$ \\
\hline$C(1)-C(6)$ & $1.5050(6)$ & $C(1)-C(2)-C(3)$ & $110.48(3)$ \\
\hline$C(1)-C(2)$ & $1.5095(6)$ & $\mathrm{C}(18)-\mathrm{N}(1)-\mathrm{C}(15)$ & $108.71(3)$ \\
\hline $\mathrm{O}(2)-\mathrm{C}(2)$ & $1.4201(6)$ & $\mathrm{C}(18)-\mathrm{N}(1)-\mathrm{C}(14)$ & $110.61(3)$ \\
\hline $\mathrm{C}(2)-\mathrm{C}(3)$ & $1.5436(9)$ & $\mathrm{C}(15)-\mathrm{N}(1)-\mathrm{C}(14)$ & $109.78(3)$ \\
\hline $\mathrm{N}(1)-\mathrm{C}(18)$ & $1.4672(6)$ & $\mathrm{C}(14)-\mathrm{C}(3)-\mathrm{C}(4)$ & $107.94(3)$ \\
\hline $\mathrm{N}(1)-\mathrm{C}(15)$ & $1.4696(6)$ & $C(14)-C(3)-C(2)$ & $111.12(3)$ \\
\hline $\mathrm{N}(1)-\mathrm{C}(14)$ & $1.4709(6)$ & $\mathrm{C}(4)-\mathrm{C}(3)-\mathrm{C}(2)$ & $111.02(3)$ \\
\hline$C(3)-C(14)$ & $1.5291(6)$ & $\mathrm{C}(16)-\mathrm{O}(1)-\mathrm{C}(17)$ & $109.57(3)$ \\
\hline$C(3)-C(4)$ & $1.5351(6)$ & $\mathrm{C}(13)-\mathrm{C}(8)-\mathrm{C}(9)$ & $117.82(4)$ \\
\hline $\mathrm{O}(1)-\mathrm{C}(16)$ & $1.4194(7)$ & $C(13)-C(8)-C(7)$ & $122.67(3)$ \\
\hline $\mathrm{O}(1)-\mathrm{C}(17)$ & $1.4231(7)$ & $\mathrm{C}(9)-\mathrm{C}(8)-\mathrm{C}(7)$ & $119.49(3)$ \\
\hline$C(8)-C(13)$ & $1.3999(6)$ & $\mathrm{N}(1)-\mathrm{C}(18)-\mathrm{C}(17)$ & $110.12(4)$ \\
\hline $\mathrm{C}(8)-\mathrm{C}(9)$ & $1.4000(8)$ & $C(1)-C(6)-C(5)$ & $110.42(3)$ \\
\hline$C(8)-C(7)$ & $1.4765(6)$ & $\mathrm{C}(12)-\mathrm{C}(13)-\mathrm{C}(8)$ & $121.30(4)$ \\
\hline $\mathrm{C}(18)-\mathrm{C}(17)$ & $1.5146(7)$ & $\mathrm{C}(1)-\mathrm{C}(7)-\mathrm{C}(8)$ & $126.57(4)$ \\
\hline$C(6)-C(5)$ & $1.5302(9)$ & $\mathrm{N}(1)-\mathrm{C}(15)-\mathrm{C}(16)$ & $110.46(3)$ \\
\hline$C(13)-C(12)$ & $1.3926(6)$ & $\mathrm{O}(1)-\mathrm{C}(17)-\mathrm{C}(18)$ & $110.48(3)$ \\
\hline$C(15)-C(16)$ & $1.5171(8)$ & $C(4)-C(5)-C(6)$ & $109.93(3)$ \\
\hline$C(5)-C(4)$ & $1.5247(6)$ & $\mathrm{N}(1)-\mathrm{C}(14)-\mathrm{C}(3)$ & $115.08(3)$ \\
\hline$C(12)-C(11)$ & $1.3884(9)$ & $\mathrm{C}(11)-\mathrm{C}(12)-\mathrm{C}(13)$ & $120.18(4)$ \\
\hline$C(11)-C(10)$ & $1.3896(8)$ & $C(12)-C(11)-C(10)$ & $119.19(4)$ \\
\hline $\mathrm{C}(9)-\mathrm{C}(10)$ & $1.3929(7)$ & $\mathrm{C}(5)-\mathrm{C}(4)-\mathrm{C}(3)$ & $112.65(3)$ \\
\hline$C(7)-C(1)-C(6)$ & $125.83(3)$ & $\mathrm{O}(1)-\mathrm{C}(16)-\mathrm{C}(15)$ & $111.41(4)$ \\
\hline$C(7)-C(1)-C(2)$ & $121.78(4)$ & $C(10)-C(9)-C(8)$ & $120.74(4)$ \\
\hline$C(6)-C(1)-C(2)$ & $112.39(3)$ & $\mathrm{C}(11)-\mathrm{C}(10)-\mathrm{C}(9)$ & $120.70(4)$ \\
\hline $\mathrm{O}(2)-\mathrm{C}(2)-\mathrm{C}(1)$ & $110.93(3)$ & & \\
\hline
\end{tabular}

We also observed a relationship between hydrophobicity and the antibacterial effect. The more hydrophobic compounds: trans $\mathbf{- 1 4}$, cis-17 and cis-20 proved to be the more effective.

Although most of the compounds lost biological activity upon reduction (3/cis-14, 3/trans14 from 6.25 to $\left.200 \mu \mathrm{g} \mathrm{mL} \mathrm{m}^{-1}\right)$, we observed that some of them retained $(\mathbf{6} /$ cis-17) or even increased their activity (9/cis $\mathbf{- 2 0}$ from 200 to $\left.50 \mu \mathrm{g} \mathrm{mL}^{-1}\right)$.

Determination of the free intracellular thiol content of the "S" and Re mutant $E$. coli treated with these compounds at MIC concentration or at $200 \mu \mathrm{g} \mathrm{mL} \mathrm{mL}^{-1}$ revealed that reduction completely abolished the thiol reactivity (Figs. 3 and 4). This supported our idea, that in some of these compounds the antibacterial activity cannot be explained by a thiol alkylation. 


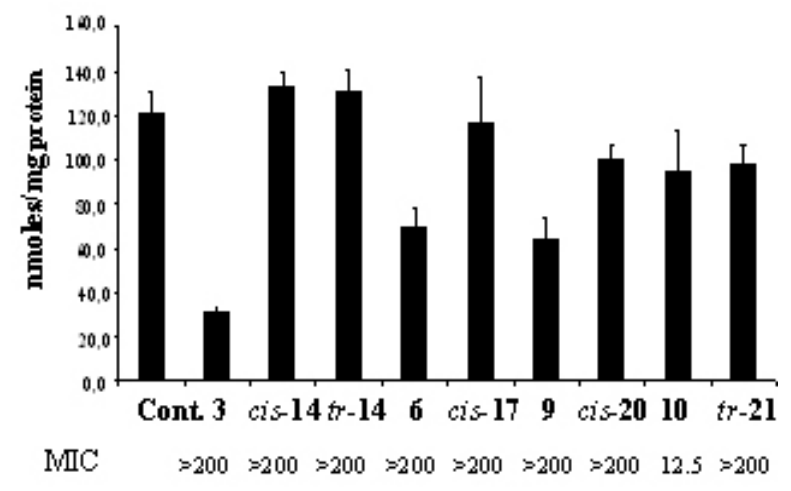

Figure 3. Thiol content in E. coli " $\mathrm{S}$ " form, the MIC values in $\mu \mathrm{g} \mathrm{mL} \mathrm{m}^{-1}$ are listed under the chart. (Cont.: control)

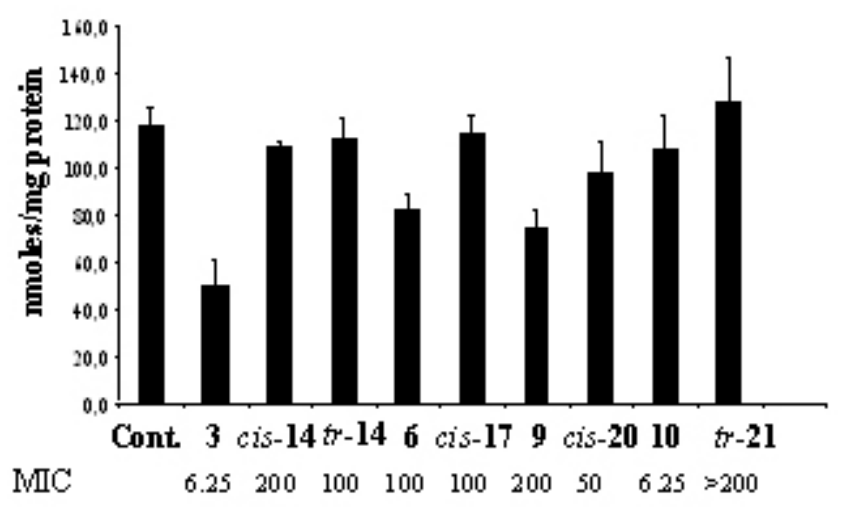

Figure 4. Thiol content in E. coli "Re" form, the MIC values in $\mu \mathrm{g} \mathrm{mL} \mathrm{L}^{-1}$ are listed under the chart. (Cont.: control)

Human cytotoxicity of our amino alcohols was evaluated against HeLa cell lines (Table 4). Similarly to the antibacterial effect, the cytotoxicity for most of the compounds diminished by the reduction, as demonstrated in the case of trans-13, trans-22, cis-14 and cis-20.

On the contrary, the cytotoxicity of cis-17 increased and it is the most toxic in this series. It is worth mentioning that the cis-14 and trans-14 stereoisomers have very different $\mathrm{IC}_{50}$ values, but very similar antibacterial activity. 
Table 3. Comparison of the in vitro antibacterial activity of the aminoalcohols (12-22 in the first line, in italics) and starting Mannich ketones (111 in the second line), expressed as minimum inhibitory concentration values (MIC, $\mu \mathrm{g} \mathrm{mL}^{-1}$ )

\begin{tabular}{|c|c|c|c|c|c|c|c|c|c|}
\hline \multicolumn{10}{|c|}{$\begin{array}{l}\text { Table 3. Comparison of the in vitro antibacterial activity of the aminoalcohols (12-22 in the first line, in italics) and starting Mannich ketones (1- } \\
\left.11 \text { in the second line), expressed as minimum inhibitory concentration values (MIC, } \mu \mathrm{g} \mathrm{mL}^{-1}\right)\end{array}$} \\
\hline No. & S. s. & S. $a$. & M. $l$. & B. s. & P. a. & E.c. & $\begin{array}{c}\text { E.c. } \\
\text { ReD31m4 }\end{array}$ & $\begin{array}{c}\text { S. } m . \\
\text { Re595 }\end{array}$ & $\begin{array}{c}\text { S. } s . \\
\text { Re4350 }\end{array}$ \\
\hline trans $\mathbf{- 1 2}$ & $>200$ & $>200$ & $>200$ & $>200$ & $>200$ & $>200$ & $>200$ & $>200$ & $>200$ \\
\hline 1 & 6.25 & 6.25 & 6.25 & 12.5 & $>200$ & 100 & 25 & 25 & 6.25 \\
\hline trans $\mathbf{- 1 3}$ & $>200$ & $>200$ & 200 & $>200$ & $>200$ & $>200$ & $>200$ & $>200$ & $>200$ \\
\hline 2 & 12.5 & 12.5 & 12.5 & 3.125 & $>200$ & 200 & 50 & 12.5 & 12.5 \\
\hline cis-14 & $>200$ & $>200$ & $>200$ & $>200$ & $>200$ & $>200$ & 200 & 100 & 100 \\
\hline 3 & 6.25 & 1.56 & 6.25 & 12.5 & $>200$ & $>200$ & 6.25 & 6.25 & 3.125 \\
\hline trans $\mathbf{- 1 4}$ & $>200$ & $>200$ & $>200$ & $>200$ & $>200$ & $>200$ & 100 & 100 & 100 \\
\hline 3 & 6.25 & 1.56 & 6.25 & 12.5 & $>200$ & $>200$ & 6.25 & 6.25 & 3.125 \\
\hline trans $\mathbf{- 1 6}$ & 200 & $>200$ & 200 & 200 & $>200$ & $>200$ & 200 & 200 & 200 \\
\hline 5 & 3.125 & 3.125 & 6.25 & 12.5 & $>200$ & $>200$ & 12.5 & 6.25 & 3.125 \\
\hline cis-17 & $>200$ & $>200$ & $>200$ & $>200$ & $>200$ & $>200$ & 100 & 100 & 100 \\
\hline 6 & 12.5 & 50 & 25 & 25 & $>200$ & $>200$ & 100 & 100 & 50 \\
\hline cis-18 & 100 & $>200$ & $>200$ & $>200$ & $>200$ & 200 & 50 & 50 & 100 \\
\hline 7 & 25 & 100 & 100 & 50 & $>200$ & $>200$ & 200 & 200 & 200 \\
\hline trans $\mathbf{- 1 8}$ & $>200$ & $>200$ & 200 & $>200$ & $>200$ & $>200$ & $>200$ & $>200$ & $>200$ \\
\hline 7 & 25 & 100 & 100 & 50 & $>200$ & $>200$ & 200 & 200 & 200 \\
\hline cis-19 & $>200$ & $>200$ & $>200$ & $>200$ & $>200$ & $>200$ & 200 & 200 & 200 \\
\hline 8 & 25 & 50 & 25 & 12.5 & $>200$ & $>200$ & 200 & 200 & 200 \\
\hline cis-20 & 200 & $>200$ & 100 & $>200$ & $>200$ & $>200$ & 50 & 50 & 50 \\
\hline 9 & 50 & 100 & 100 & 100 & $>200$ & $>200$ & 200 & 200 & 200 \\
\hline trans $\mathbf{- 2 1}$ & $>200$ & $>200$ & $>200$ & $>200$ & $>200$ & $>200$ & $>200$ & $>200$ & $>200$ \\
\hline 10 & 6.25 & 6.25 & 6.25 & 6.25 & 200 & 12.5 & 6.25 & 3.125 & 3.125 \\
\hline trans $\mathbf{- 2 2}$ & $>200$ & $>200$ & $>200$ & $>200$ & $>200$ & $>200$ & $>200$ & $>200$ & $>200$ \\
\hline 11 & 25 & 25 & 25 & 50 & $>200$ & $>200$ & 25 & 25 & 50 \\
\hline
\end{tabular}


S. s.: Staphylococcus saprophyticus NIH Hungary 120008;

S. a.: Staphylococcus aureus NIH Hungary 118003;

M. l.: Micrococcus luteus ATCC 9341;

B. s.: Bacillus subtilis ATCC 6633;

E. c.: Escherichia coli ATCC 25922;

P. a.: Pseudomonas aeruginosa NIH Hungary 170000;

E. c.: ReD31m4: Escherichia coli ReD31m4;

S. m.: Re595: Salmonella minnesota Re595;

S. s.: Re4350: Shigella sonnei Re4350.

Table 4. In vitro cytotoxicity of of aminoalcohols on HeLa cell line, expressed as $\mathrm{IC}_{50}$

\begin{tabular}{cc}
\hline Comp. & $\mathrm{IC}_{50}(\mathrm{nM} / \mathrm{mL})$ \\
\hline trans $\mathbf{- 1 2}$ & 153.79 \\
trans $\mathbf{- 1 3}$ & 265,40 \\
cis-14 & $>278,35$ \\
trans $\mathbf{- 1 4}$ & 145,19 \\
trans $\mathbf{- 1 6}$ & $>267,15$ \\
cis-17 & 60,71 \\
cis-18 & 260.00 \\
trans $\mathbf{- 1 8}$ & $>267,15$ \\
cis-19 & $>253,60$ \\
cis-20 & 239,28 \\
trans $\mathbf{- 2 1}$ & $>342,88$ \\
trans $-\mathbf{2 2}$ & $>345,81$ \\
\hline
\end{tabular}

\section{Conclusions}

In conclusion, reduction of $\mathbf{3}$ with various complex hydrides afforded reaction mixtures of very different stereocomposition. Reduction with sodium borohydride was found to be diasteroselective both for $\alpha, \beta$-unsaturated- and fused Mannich ketones. The stereocomposition of the reaction mixtures was influenced by the size of the ring. The predominance of the trans isomers as trans-14 can be explained by the intramolecular hydrogen bond between the $\mathrm{OH}$ and the $\mathrm{N}$ as demonstrated by crystal structure analysis. Most of the amino alcohols almost completely lost their biological effect. Two compounds, however, retained or even increased their antibacterial activity on deep rough mutants (9/cis-20 MIC: from 200 to $\left.50 \mu \mathrm{g} \mathrm{mL}^{-1}\right)$ and thus emerged as lead compounds for antibacterial agents with a unique, yet currently unknown, activity profile. Since the amino alcohols did not cause thiol depletion, this finding points to a new mechanism of action other than alkylation. The MIC values for deep rough mutants show that the permeability of the outer membrane definitely can influence the antibacterial activity of our compounds. The cytotoxic activities of the amino alcohols also were evaluated using HeLa 
cells. Most of the reduced derivatives proved to be less toxic to the HeLa cells than the starting Mannich ketones, consistent with data obtained with bacteria. The effect of two amino alcohols, however, was significantly different in HeLa cells and in bacteria. Cis-17 increased its toxicity in HeLa but was not active against bacteria, cis-20 became nontoxic in HeLa but displayed antibacterial activity.

\section{Experimental Section}

General Procedures. The diethyl ether used for the reductions was dried by distillation 12 from $\mathrm{Na}$ under Ar. Our starting Mannich ketones (1-9 and 10-11) are known compounds synthesised according to our methods ${ }^{1,2}$ or literature methods. ${ }^{9}$ In all of the unsaturated Mannich ketones the configuration is $E$ around the $\mathrm{C}=\mathrm{C}$ double bond. ${ }^{1}$ Thin-layer chromatography (TLC) was performed on Merck silica gel plates $\left(60 \mathrm{~F}_{254}\right)$, using ethyl acetate-benzene $(10: 1 \mathrm{v} / \mathrm{v})$ as eluent. Melting points were determined on a Boetius apparatus and are uncorrected. The analytical values were within $\pm 0.4 \%$ of the theoretical values for $\mathrm{C}, \mathrm{H}$ and $\mathrm{N}$.

The structure elucidation of compounds 12-22 was performed by NMR measurements. NMR spectra were recorded with a Varian UNITY INOVA $400 \mathrm{WB}\left(400 / 100 \mathrm{MHz}\right.$ for $\left.{ }^{1} \mathrm{H} /{ }^{13} \mathrm{C}\right)$ spectrometer. Chemical shifts are referenced to $\mathrm{Me}_{4} \mathrm{Si}\left({ }^{1} \mathrm{H}\right)$ or to the residual solvent signals $\left({ }^{13} \mathrm{C}\right)$. Measurements were run at $298 \mathrm{~K}$ or $300 \mathrm{~K}$ probe temperatures. The ${ }^{1} \mathrm{H}$ and ${ }^{13} \mathrm{C}$ assignments were based on ${ }^{1} \mathrm{H}-{ }^{1} \mathrm{H}$ COSY, gradient enhanced ${ }^{13} \mathrm{C}-{ }^{1} \mathrm{H}$ HSQC and ${ }^{13} \mathrm{C}-{ }^{1} \mathrm{H}$ HMBC experiments executed using standard Varian software.

[The NOE correlations between the corresponding $\mathrm{CH}_{2}$ proton of the saturated cycloalkane ring and the aromatic protons $\left(\mathrm{H}^{2} 2^{\prime}, 6^{\prime}\right)$ in the corresponding NOESY spectra proved the $E$ configuration of compounds trans-12 - cis-20.] The cis/trans orientation of bonds C1-H1/C2-H2 (in trans-12 - cis-20) and $\mathrm{C} 1-\mathrm{H} 1 / \mathrm{C} 8-\mathrm{H} 8$ (in trans-21 and trans-22) each to other are evident from the corresponding vicinal ${ }^{1} \mathrm{H}-{ }^{1} \mathrm{H}$ coupling constant values (see Experimental). The presence of NOE correlations between $\mathrm{H}-1 / \mathrm{H}-2$ in the corresponding NOESY spectra of cis-14 and cis-17 - cis-20 and the lack of the same correlations for trans-12 - trans-18 as well as the lack of NOE correlations between H-1 and H-8 in the corresponding NOESY spectra of trans-21 and trans-22 also corroborate the cis and trans orientations, respectively.

FT-IR spectra were taken on a Nicolet Impact 400 spectrophotometer in $\mathrm{KBr}$ pellets.

X-Ray structure determination of trans-14. $C_{18} H_{25} N O, M_{r}=287.39$, transparent crystal of size $0.3 \times 0.3 \times 0.1 \mathrm{~mm}^{3}$, triclinic, space group $\mathrm{P} \overline{1}\left(\right.$ No. 2 of $\left.\mathrm{IT}^{1}\right)$. Lattice parameters are $\mathrm{a}=5.575(3) \AA$, $\mathrm{b}=10.207(4) \AA, \mathrm{c}=14.486(5) \AA, \alpha=74.687(6)^{\circ}, \beta=89.945(6)^{\circ}, \gamma=85.481(9)^{\circ}$ and $\mathrm{V}=792.4(6)$ $\AA^{3}$ (determined from 17676 reflections, $\left.3^{\circ}<\theta<30^{\circ}\right), Z=2, d_{\text {calc }}=1.204 \mathrm{~g} \mathrm{~cm}^{-3}$ and $\mu_{x}(\lambda=0.49592$ $\AA)=0.18 \mathrm{~cm}^{-1}$. Reflections were recorded at $100 \mathrm{~K}$ using a CCD-detector (MarCCD 165) and monochromatic synchrotron radiation $(\lambda=0.49592 \AA)$. Reflections were indexed, integrated, corrected and scaled using XDS. ${ }^{10}$ The same program was used to refine the lattice parameters. A long and a short exposure time series each with $360^{\circ}$ of total oscillation range and with $0.5^{\circ}$ per 
frame were recorded. Data were integrated for $-11 \leq \mathrm{h} \leq 11,-20 \leq \mathrm{k} \leq 21$ and $-29 \leq 1 \leq 29$ with $(\sin \theta / \lambda)_{\max }=1.04$. Total number of observations was 87736 with 13034 unique $\left(R_{\text {merge }}=2.1 \%\right)$. All unique reflections were used for further analysis. The structure was solved by direct methods ${ }^{11}$. All non-H atoms were refined anisotropically using full matrix least-square ${ }^{12}$ based on $F^{2}$ with weights $1 /\left[\sigma^{2}\left(F_{o}^{2}\right)+\left(0.0633^{*} P\right)^{2}+0.07 * P\right]$ where $P=\left(\operatorname{Max}\left(F_{o}^{2}, 0\right)+2 * F_{c}^{2}\right) / 3$. For each $\mathrm{H}$-atom the co-ordinates and an isotropic displacement parameter were refined. The shifts $(\Delta / \sigma)^{\max }$ of the final least square cycle were smaller than 0.002 . R-values for $F^{2}>2 \sigma\left(F^{2}\right)$ were $R$ $=0.0393$ (based on $|F|$ ) and $R_{w}=0.1159$ (based on $F^{2}$ ). Goodness of fit was 1.074. The final difference Fourier was featureless with the highest maxima at the positions of the binding electrons $\left(\Delta \rho_{\min }=-0.32, \Delta \rho_{\max }=0.67\right)$. All relevant crystallographic data have been deposited with the Cambridge Crystallographic Data Center under the number CCDC 197256.

Theoretical calculations. CAChe Worksystem Pro (version 5.04, Fujitsu America, Inc., Beaverton, OR), a personal computer-based molecular modeling program, was used in the computational studies. Geometry-optimized molecular models (in vacuo, gradient norm below $0.1 \mathrm{kcal} / \AA$ as the criterion for convergence) and $\Delta \mathrm{H}_{\mathrm{f}}{ }^{\circ}$ values for cis/trans-3a-e were obtained by a semi-empirical quantum mechanical method (PM5 parameters).

Biological procedure. Determination of antibacterial activity. MIC values were determined by the broth macrodilution method ${ }^{14}$ as described previously. ${ }^{1}$ The water soluble hydrochlorides of the aminoalcohols were screened. The test bacteria were Pseudomonas aeruginosa NIH Hungary 170000, E. coli ATCC 25922, E. coli ReD31m4, S. minnesota Re595, S. sonnei Re4350, S. saprophyticus NIH Hungary 120008, S. aureus NIH Hungary 118003, M. luteus ATCC 9341 and B. subtilis ATCC 6633. The tube dilution method started with making twofold dilution series of test compounds in nutrient broth. The test bacteria were in the logarithmic phase; their final concentration was ca. $5 \times 10^{5}$ colony-forming units $\mathrm{mL}^{-1}$. The MIC values were determined after one night incubation $\left(37^{\circ} \mathrm{C}\right)$ as the lowest concentration of compounds producing no visible bacterial growth. All experiments were performed in triplicate.

In vitro effect of Mannich ketones on HeLa cell line. ${ }^{1}$ The HeLa cells were cultured in RPMI1640 culture medium containing $10 \%$ heat-inactivated fetal calf serum with antibiotics streptomycin $\left(25 \mu \mathrm{g} \mathrm{mL}^{-1}\right)$ and penicillin $\left(50 \mu \mathrm{g} \mathrm{mL}^{-1}\right)$. The cells were grown as a monolayer, in the logarithmic phase, had viability better than $98 \%$ as proved by Tripan blue exclusion. The growing cells were plated out in $100 \mu \mathrm{L}$ of medium at concentration of $4-5 \times 10^{3}$ cells/flatbottomed well in 96-well microtiter plates. Plates were incubated for 24 hours at $37{ }^{\circ} \mathrm{C}$ in a humidified atmosphere of $5 \% \mathrm{CO}_{2} .100 \mu \mathrm{L}$ of media containing the drug dissolved in appropriate solvent were added to each well and incubated for a further 48 hours. MTT was filtered through a $0.22 \mu \mathrm{m}$ filter and diluted in RPMI-1640 containing antibiotics to $1 \mathrm{mg} \mathrm{mL}^{-1} .100 \mu \mathrm{l}$ of this solution added to each well and incubated for 4 hours. All untransformed MTT (medium) was removed by careful aspiration from the wells. The formazan crystals were dissolved in $100 \mu \mathrm{L}$ of isopropanol-1 $\mathrm{N} \mathrm{HCl}(24 / 1 \mathrm{v} / \mathrm{v})$. Then the plate was shaken in order to ensure solubilization of the blue formazan crystals. The absorbance was recorded in an enzyme-linked immunosorbent assay plate reader at a $560 \mathrm{~nm}$ test wavelength and a $690 \mathrm{~nm}$ reference wavelength. 
Determination of free thiol content. The method was published previously. ${ }^{1}$ Shortly, the bacterial cells were cultivated in a shaker incubator $\left(37^{\circ} \mathrm{C}\right)$ to the mid log phase and treated with the different compounds at the MIC concentration or at $200 \mu \mathrm{g} \mathrm{m} l^{-1}$ in cases of ineffective substances $\left(\mathrm{MIC}>200 \mu \mathrm{g} \mathrm{mL} \mathrm{m}^{-1}\right.$ ) for one hour. The treated cells were centrifuged $\left(+4{ }^{\circ} \mathrm{C}\right.$ ), washed with physiological saline solution and stored at $-80^{\circ} \mathrm{C}$ as pellets. These cell pellets were resuspended in a buffer containing $50 \mathrm{mM}$ TRIS-HCl, $0.1 \%$ SDS of $\mathrm{pH} 7.4$, and lysed by sonication. The cell lysates were clarified by centrifugation and used immediately for the determination of free thiol by the DTNB assay. ${ }^{15}$ The protein concentration was determined by the BCA (bicinchoninic acid) assay. ${ }^{16}$ The assay was repeated using eight selected compounds in three parallel cultures. Values represent the average of three independent determinations \pm SD.

\section{General procedure for the reductions with $\mathrm{NaBH}_{4}$}

To a methanol solution $(50 \mathrm{~mL})$ of the appropriate Mannich ketone $(2 \mathrm{mmol})$, equivalent aqueous $\mathrm{NaOH}$ solution $(10 \mathrm{~mL}, 2 \mathrm{mmol})$ was added at $0{ }^{\circ} \mathrm{C}$ under stirring. Then, sodium borohydride $(8 \mathrm{mmol})$ was added in small portions during $20 \mathrm{~min}$. The solution was stirred at room temperature for $24 \mathrm{~h}$. It was cooled to $0{ }^{\circ} \mathrm{C}$ and acidified with concentrated $\mathrm{HCl}$. After 20 min its $\mathrm{pH}$ was adjusted with aqueous $\mathrm{NaOH}$ to $\mathrm{pH} 10$ and evaporated to the half of the original volume. Water was added and the resulting slurry was extracted with chloroform $(3 \mathrm{x} 80 \mathrm{~mL})$. The chloroform extracts were combined and washed with brine and dried over sodium sulphate. The chloroform solution was evaporated to dryness under reduced pressure. The oily residue was purified by column chromatography using Brockman II neutral $\mathrm{Al}_{2} \mathrm{O}_{3}$ and different benzenetriethylamine mixtures as eluents as follows: benzene/triethylamine 10/0.2 (trans-15, trans-21); 10/0.3 (trans-12, trans-13, cis-14, trans-14, cis-20, trans-22); 10/0.4 v/v (cis-17- trans-17).

trans-E-2-Phenylmethylene-5-piperidin-1-ylmethyl-cyclopentanol (12). Colorless crystals; yield $87 \%$; mp $81{ }^{\circ} \mathrm{C}$ (from hexane-ether mixture, dec.). Anal. calcd. for $\mathrm{C}_{18} \mathrm{H}_{25} \mathrm{NO}$ : $\mathrm{C}, 79.66 ; \mathrm{H}$, 9.28; N, 5.16; found: C, 79.55; H, 9.39; N, 5.10. IR (KBr) v $\max : 3365,2941,2922,2886,2854$, 2814, 2782, 1597, 1489, 1447, 1409, 1121, 1040, 757 and $695 \mathrm{~cm}^{-1} .{ }^{1} \mathrm{H} \mathrm{NMR}\left(400 \mathrm{MHz}, \mathrm{CDCl}_{3}\right)$ $\delta_{\mathrm{H}}: 1.26\left(\mathrm{~m}, 1 \mathrm{H}, J=12.3,9.6 \mathrm{~Hz}, \mathrm{CH}_{2}, \mathrm{H}-3\right), 1.45$ (m, 2H, $\mathrm{CH}_{2}, \mathrm{H}-4$ "), 1.60 (m, 4H, CH $2, \mathrm{H}-$ 3",5”), 1.82 (m, 1H, CH, $\mathrm{H}-3$ ), 1.94 (m, 1H, CH, H-2), 2.33 (bs, 2H, CH $2, \mathrm{H}-2$ ",6”), 2.39 (t, 1H,

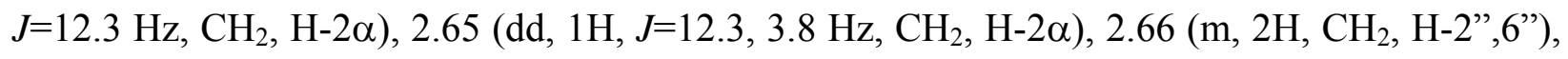
2.69 (m, 2H, $\left.\mathrm{CH}_{2}, \mathrm{H}-4\right), 4.25$ (d, 1H, J=9.7 Hz, CH, H-1), 5.78 (bs, 1H, -OH), 6.47 (q, 1H, $J=2.4 \mathrm{~Hz},=\mathrm{CH}, \mathrm{H}-8 \alpha), 7.16\left(\mathrm{~m}\right.$, aromatic, $\left.1 \mathrm{H}, \mathrm{H}-4^{\prime}\right), 7.30$ (m, aromatic, $\left.2 \mathrm{H}, \mathrm{H}-3^{\prime}, 5^{\prime}\right), 7.36$ (m, aromatic, 2H, H-2',6'); ${ }^{13} \mathrm{C}$ NMR (100 MHz, $\mathrm{CDCl}_{3}$ ) $\delta_{\mathrm{C}} 24.1$ (C-4”), 25.1 (C-3), 26.1 (C-3”,5”),

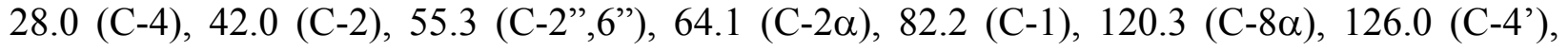
128.1 (C-3',5'), 128.3 (C-2',6'), 138.0 (C-1'), 145.0 (C-8).

trans-E-2-(4'-Methoxy-phenylmethylene)-5-piperidin-1-ylmethyl-cyclopentanol (13).

Colorless crystals; yield 67\%; mp $95{ }^{\circ} \mathrm{C}$ (from hexane-ether mixture, dec.). Anal. calcd. for $\mathrm{C}_{19} \mathrm{H}_{27} \mathrm{NO}_{2}$ : C, 75.71; H, 9.03; N, 4.65; found: C, 75.83; H, 9.21; N, 4.51. IR (KBr) v ${ }_{\text {max }}$ : 3303, 2945, 2936, 2887, 2860, 1604, 1510, 1455, 1294, 1249, 1177, 1114, 1028, 820 and $530 \mathrm{~cm}^{-1} .{ }^{1} \mathrm{H}$ NMR (400 MHz, CDCl $\left.{ }_{3}\right) \delta_{\mathrm{H}}: 1.25\left(\mathrm{~m}, 1 \mathrm{H} \mathrm{J}=12.2,9.6 \mathrm{~Hz}, \mathrm{CH}_{2}, \mathrm{H}-3\right), 1.44$ (m, 2H, CH, $\mathrm{H}-4$ ”), 1.59 (m, 4H, CH, H-3",5”), 1.81 (m, 1H, CH, $\mathrm{H}-3$ ), 1.92 (m, 1H, CH, H-2), 2.32 (bs, 2H, $\mathrm{CH}_{2}$, 
H-2",6”), 2.38 (t, 1H, J=12.2 Hz, $\mathrm{CH}_{2}, \mathrm{H}-2 \alpha$ ), 2.63 (dd, 1H, $J=12.2,3.8 \mathrm{~Hz}, \mathrm{CH}_{2}, \mathrm{H}-2 \alpha$ ), 2.65 (m, 2H, CH $2, \mathrm{H}-2$ ", 6"), 2.65 (m, 2H, CH $2, \mathrm{H}-4), 3.78$ (s, 3H, - $\left.\mathrm{OCH}_{3}\right), 4.23$ (d, $1 \mathrm{H}, J=9.7 \mathrm{~Hz}$, $\mathrm{CH}, \mathrm{H}-1), 5.74(\mathrm{bs}, 1 \mathrm{H},-\mathrm{OH}), 6.41(\mathrm{q}, 1 \mathrm{H}, \mathrm{J}=2.5 \mathrm{~Hz},=\mathrm{CH}, \mathrm{H}-8 \alpha), 6.84$ (m, aromatic, $2 \mathrm{H}, \mathrm{H}-$ $\left.3^{\prime}, 5^{\prime}\right), 7.29$ (m, aromatic, 2H, H-2',6'); ${ }^{13} \mathrm{C}$ NMR (100 MHz, CDCl $\left.{ }_{3}\right) \delta_{\mathrm{c}}: 24.1$ (C-4"), $25.2(\mathrm{C}-3)$, 26.1 (C-3",5”), 27.9 (C-4), 42.1 (C-2), $55.2\left(-\mathrm{OCH}_{3}\right), 55.3$ (C-2",6”), 64.1 (C-2 $\left.\alpha\right), 82.2$ (C-1),

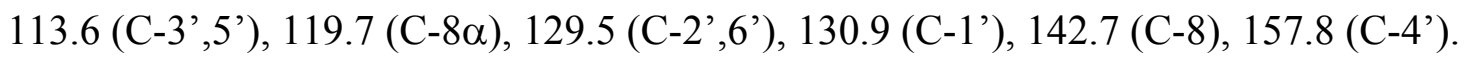

cis-E-2-Phenylmethylene-6-morpholin-1-ylmethyl-cyclohexanol (14). Colorless crystals; yield $89 \%$ for cis- and tr-14; mp $104{ }^{\circ} \mathrm{C}$ (hexane-ether, dec.). Anal. calcd. for $\mathrm{C}_{18} \mathrm{H}_{25} \mathrm{NO}_{2}$ : C, 75.22; H, 8.77; N, 4.87; found: C, 75.32; H, 8.89; N, 4.71. IR (KBr) v $v_{\max }$ : 3153, 2960, 2947, 2931, 2924, 2855, 2825, 1597, 1489, 1291, 1266, 1115, 1005, 985, 869, 747 and $702 \mathrm{~cm}^{-1} .{ }^{1} \mathrm{H}$ NMR (400 MHz, $\left.\mathrm{CDCl}_{3}\right) \delta_{\mathrm{H}}: 1.42\left(\mathrm{~m}, 1 \mathrm{H}, \mathrm{CH}_{2}, \mathrm{H}-4\right), 1.54\left(\mathrm{~m}, 1 \mathrm{H}, \mathrm{CH}_{2}, \mathrm{H}-4\right), 1.59(\mathrm{~m}, 1 \mathrm{H}$, $\left.\mathrm{CH}_{2}, \mathrm{H}-3\right), 1.74$ (m, $\left.1 \mathrm{H}, \mathrm{CH}_{2}, \mathrm{H}-3\right), 1.89$ (m, 1H, $\mathrm{CH}_{2}, \mathrm{H}-5$ ), 2.22 (ddd, $1 \mathrm{H}, J=12.3,2.9,1.2 \mathrm{~Hz}$, $\mathrm{CH}_{2}, \mathrm{H}-2 \alpha$ ), 2.36 (m, 2H, CH $2, \mathrm{H}-2$ ", 6"), 2.51 (m, 1H, CH, H-2), 2.69 (m, 2H, $\mathrm{CH}_{2}, \mathrm{H}-2$ ", 6"), 2.89 (m, 1H, $\left.\mathrm{CH}_{2}, \mathrm{H}-5\right), 2.95$ (t, 1H, J=12.3 Hz, CH (d, 1H, J=4.0 Hz, CH, H-1), 6.72 (bs, $1 \mathrm{H},=\mathrm{CH}, \mathrm{H}-8 \alpha$ ), 7.21 (m, aromatic, 1H, H-4'), 7.23 (m, aromatic, 2H, H-2',6'), 7.32 (m., aromatic, $\left.2 \mathrm{H}, \mathrm{H}-3^{\prime}, 5^{\prime}\right) ;{ }^{13} \mathrm{C} \mathrm{NMR}\left(100 \mathrm{MHz}, \mathrm{CDCl}_{3}\right) \delta_{\mathrm{C}}: 23.1$ (C-4), 27.8 (C-5), 28.7 (C-3), 36.7 (C-2), 54.0 (C-2",6”), 60.1 (C-2a), 66.9 (C-3",5”), 76.9 (C-1),

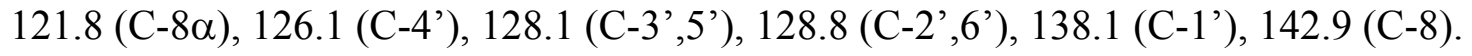

trans-E-2-Phenylmethylene-6-morpholin-1-ylmethyl-cyclohexanol (14). Colorless crystals; mp $73{ }^{\circ} \mathrm{C}$ (from hexane-ether mixture dec.). Anal. calcd. for $\mathrm{C}_{18} \mathrm{H}_{25} \mathrm{NO}_{2}$ : C, 75.22; $\mathrm{H}, 8.77 ; \mathrm{N}$, 4.87; found: C, 75.17; H, 8.91; N, 4.95. IR (KBr) $v_{\max }$ : 3197, 2972, 2922, 2847, 2825, 1599, 1494, 1461, 1443, 1285, 1116, 864, 747 and $704 \mathrm{~cm}^{-1} .{ }^{1} \mathrm{H}$ NMR $\left(400 \mathrm{MHz}, \mathrm{CDCl}_{3}\right) \delta_{\mathrm{H}}: 1.13(\mathrm{~m}$, 1H, $\left.\mathrm{CH}_{2}, \mathrm{H}-3\right), 1.34$ (m, 1H, $\left.\mathrm{CH}_{2}, \mathrm{H}-4\right), 1.61\left(\mathrm{~m}, 1 \mathrm{H}, \mathrm{CH}_{2}, \mathrm{H}-3\right), 1.73$ (m, 1H, $\left.\mathrm{CH}_{2}, \mathrm{H}-5\right), 1.75$ (m, 1H, CH, H-2), 1.77 (m, 1H, CH, $\mathrm{H}-4$ ), 2.41 (bs, 2H, $\mathrm{CH}_{2}, \mathrm{H}-2$ ",6"), 2.44 (dd, 1H, J=12.6, $2.8 \mathrm{~Hz}, \mathrm{CH}_{2}, \mathrm{H}-2 \alpha$ ), 2.56 ( $\psi \mathrm{t}, 1 \mathrm{H}, J=12.6,11.5 \mathrm{~Hz}, \mathrm{CH}_{2}, \mathrm{H}-2 \alpha$ ), 2.73 (bs, $2 \mathrm{H}, \mathrm{CH}_{2}, \mathrm{H}-2$ ", 6"), 2.95 (m, 1H, $\mathrm{CH}_{2}, \mathrm{H}-5$ ), 3.74 (m, 4H, CH $2, \mathrm{H}-3$ ", 5"), 4.03 (dd, 1H, J=9.5, $1.8 \mathrm{~Hz}, \mathrm{CH}, \mathrm{H}-1$ ), $6.71(\mathrm{bs}, 1 \mathrm{H},=\mathrm{CH}, \mathrm{H}-8 \alpha), 7.17$ (m, aromatic, $\left.1 \mathrm{H}, \mathrm{H}-4^{\prime}\right), 7.23$ (m, aromatic, $\left.2 \mathrm{H}, \mathrm{H}-2^{\prime}, 6^{\prime}\right), 7.30$ (m., aromatic, $\left.2 \mathrm{H}, \mathrm{H}-3^{\prime}, 5^{\prime}\right) ;{ }^{13} \mathrm{C} \mathrm{NMR}\left(100 \mathrm{MHz}, \mathrm{CDCl}_{3}\right) \delta_{\mathrm{C}}: 26.6(\mathrm{C}-4), 27.6(\mathrm{C}-5), 29.0(\mathrm{C}-3)$,

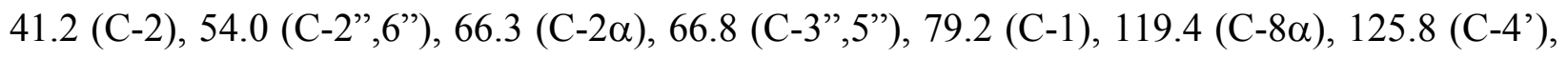
127.9 (C-3',5'), 128.9 (C-2',6'), 138.5 (C-1'), 142.4 (C-8).

trans-E-2-Phenylmethylene-6-pyrrolidin-1-ylmethyl-cyclohexanol (15). It was not possible to isolate the pure compound due to instability; yield $85 \%$. ${ }^{1} \mathrm{H}$ NMR $\left(400 \mathrm{MHz}, \mathrm{CDCl}_{3}\right) \delta_{\mathrm{H}}: 1.13$ (m, $\left.1 \mathrm{H}, J=13.0,3.8 \mathrm{~Hz}, \mathrm{CH}_{2}, \mathrm{H}-3\right), 1.34\left(\mathrm{~m}, 1 \mathrm{H}, J=13.0,5.4,3.4 \mathrm{~Hz}, \mathrm{CH}_{2}, \mathrm{H}-4\right), 1.64(\mathrm{~m}, 1 \mathrm{H}$, $\left.\mathrm{CH}_{2}, \mathrm{H}-3\right), 1.70(\mathrm{~m}, 1 \mathrm{H}, \mathrm{CH}, \mathrm{H}-2), 1.74\left(\mathrm{~m}, 1 \mathrm{H}, \mathrm{CH}_{2}, \mathrm{H}-5\right), 1.77$ (m, $\left.1 \mathrm{H}, \mathrm{CH}_{2}, \mathrm{H}-4\right), 1.80$ (m, 4H, $\mathrm{CH}_{2}, \mathrm{H}-3$ ", 4"), 2.37 (dd, 1H, J=12.1, $2.6 \mathrm{~Hz}, \mathrm{CH}_{2}, \mathrm{H}-2 \alpha$ ), 2.53 (m, 2H, $\mathrm{CH}_{2}, \mathrm{H}-2$ ", 5"), 2.77 (m, 2H, $\mathrm{CH}_{2}, \mathrm{H}-2$ ",5”), 2.92 (t, 1H, J=12.1 Hz, CH, $\mathrm{H}-2 \alpha$ ), 2.96 (m, 1H, $\mathrm{CH}_{2}, \mathrm{H}-5$ ), 4.03 (dd, $1 \mathrm{H}, J=9.6,1.8 \mathrm{~Hz}, \mathrm{CH}, \mathrm{H}-1), 6.71$ (bs, $1 \mathrm{H},=\mathrm{CH}, \mathrm{H}-8 \alpha), 7.17$ (m, aromatic, $1 \mathrm{H}, \mathrm{H}-4$ '), 7.23 (m, aromatic, $\left.2 \mathrm{H}, \mathrm{H}-2^{\prime}, 6^{\prime}\right), 7.30$ (m, aromatic, $\left.2 \mathrm{H}, \mathrm{H}-3^{\prime}, 5^{\prime}\right) ;{ }^{13} \mathrm{C} \mathrm{NMR}\left(100 \mathrm{MHz}, \mathrm{CDCl}_{3}\right) \delta_{\mathrm{C}}: 23.5$ (C-3”,4”), 26.7 (C-4), 27.6 (C-5), 29.2 (C-3), 43.6 (C-2), 54.4 (C-2”,5”), 63.4 (C-2 $\alpha$ ), 79.5 (C-1),

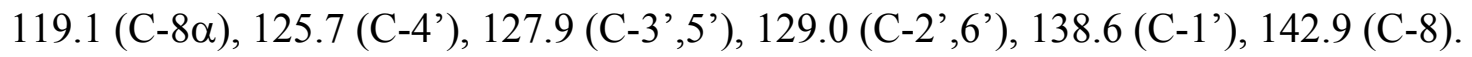


trans-E-2-Phenylmethylene-6-(4'-methyl-piperidin)-1-ylmethyl-cyclohexanol (16). Colorless crystals; yield $76 \%$; mp $79^{\circ} \mathrm{C}$ (from hexane-ether mixture, dec.). Anal. calcd. for $\mathrm{C}_{20} \mathrm{H}_{29} \mathrm{NO} \mathrm{C}$, 80.22; H, 9.76; N, 4.68; found: C, 80.31; H, 9.92; N, 4.58. IR (KBr) v $\max$ : 3126, 2945, 2921, 2883, 2863, 2768, 1596, 1493, 1441, 1119, 1103, 972, 846 and $700 \mathrm{~cm}^{-1}$. ${ }^{1} \mathrm{H}$ NMR (400 MHz, $\left.\mathrm{CDCl}_{3}\right) \delta_{\mathrm{H}}: 0.91\left(\mathrm{~d}, 3 \mathrm{H}, J=6.2 \mathrm{~Hz}, \mathrm{CH}_{3}\right), 1.10\left(\mathrm{~m}, 1 \mathrm{H}, J=13.0,3.7 \mathrm{~Hz}, \mathrm{CH}_{2}, \mathrm{H}-3\right), 1.25(\mathrm{~m}, 1 \mathrm{H}$, $\mathrm{CH}_{2}, \mathrm{H}-5$ "), 1.30 (m, 1H, CH , H-3"), 1.33 (m, 1H, $\left.\mathrm{CH}_{2}, \mathrm{H}-4\right), 1.37$ (m, 1H, CH, H-4”), 1.58 (m, 1H, $\left.\mathrm{CH}_{2}, \mathrm{H}-3\right), 1.63$ (m, 1H, CH, $\mathrm{H}-5$ "), 1.64 (m, 1H, $\mathrm{CH}_{2}, \mathrm{H}-3$ ”), 1.71 (m, 1H, CH, $\left.\mathrm{H}-5\right), 1.73$ (m, 1H, CH, H-2), 1.76 (m, 1H, CH, $\mathrm{H}-4), 1.81$ (m, 1H, $\mathrm{CH}_{2}, \mathrm{H}-6$ ”), 2.17 (t, 1H, J= $10.9 \mathrm{~Hz}$, $\mathrm{CH}_{2}, \mathrm{H}-2$ "), 2.37 (dd, $1 \mathrm{H}, J=12.5,2.9 \mathrm{~Hz}, \mathrm{CH}_{2}, \mathrm{H}-2 \alpha$ ), 2.53 (t, $1 \mathrm{H}, J=12.5 \mathrm{~Hz}, \mathrm{CH}_{2}, \mathrm{H}-2 \alpha$ ), 2.89 (m, 1H, $\mathrm{CH}_{2}, \mathrm{H}-2$ "), 2.94 (m, 1H, $\mathrm{CH}_{2}, \mathrm{H}-5$ ), 3.19 (d, 1H, J=10.9 Hz, $\mathrm{CH}_{2}, \mathrm{H}-6$ "), 4.00 (dd, 1H, $J=9.7,2.0 \mathrm{~Hz}, \mathrm{CH}, \mathrm{H}-1), 6.71$ (bs, $1 \mathrm{H},=\mathrm{CH}, \mathrm{H}-8 \alpha), 7.16$ (m, aromatic, $1 \mathrm{H}, \mathrm{H}-4$ '), 7.23 (m, aromatic, 2H, H-2',6'), 7.29 (m, aromatic, $\left.2 \mathrm{H}, \mathrm{H}-3^{\prime}, 5^{\prime}\right) ;{ }^{13} \mathrm{C} \mathrm{NMR}\left(100 \mathrm{MHz}, \mathrm{CDCl}_{3}\right) \delta_{\mathrm{C}}: 21.6$ $\left(\mathrm{CH}_{3}\right), 26.6$ (C-4), 27.6 (C-5), 29.0 (C-3), 30.5 (C-4”), 33.8 (C-5”), 34.5 (C-3”), 41.7 (C-2), 52.9

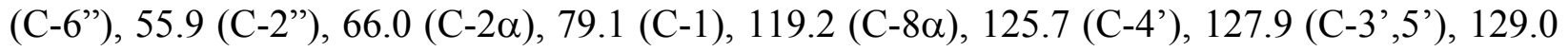
(C-2',6'), 138.6 (C-1'), 142.8 (C-8).

cis-E-2-Phenylmethylene-7-morpholin-1-ylmethyl-cycloheptanol (17). Colorless crystals; yield $90 \%$ for cis- and $t r-17$; mp $79{ }^{\circ} \mathrm{C}$ (from hexane-ether mixture, dec.). Anal. calcd. for $\mathrm{C}_{19} \mathrm{H}_{27} \mathrm{NO}_{2}$ : C, 75.71; H, 9.03; N, 4.65; found: C, 75.81; H, 9.16; N, 4.52. IR (KBr) v max: 3213, 2956, 2927, 2853, 2831, 1599, 1489, 1459, 1290, 1269, 1115, 1006, 866, 759 and $700 \mathrm{~cm}^{-1} .{ }^{1} \mathrm{H}$ NMR (400 MHz, CDCl 3$) \delta_{\mathrm{H}}: 1.31\left(\mathrm{~m}, 1 \mathrm{H}, \mathrm{CH}_{2}, \mathrm{H}-3\right), 1.51\left(\mathrm{~m}, 2 \mathrm{H}, \mathrm{CH}_{2}, \mathrm{H}-4\right), 1.65$ (m, 2H, $\mathrm{CH}_{2}, \mathrm{H}-3$ and H-5), 1.75 (m, 1H, $\left.\mathrm{CH}_{2}, \mathrm{H}-5\right), 2.18$ (dd, $\left.1 \mathrm{H}, \mathrm{J}=12.6,3.0 \mathrm{~Hz}, \mathrm{CH}_{2}, \mathrm{H}-2 \alpha\right), 2.18$ (m, 1H, CH, H-6), 2.40 (m, 2H, CH, H-2",6"), 2.42 (m, 1H, CH, H-2), 2.67 (m, 2H, CH, H-2",6"), 2.71 (m, 1H, CH $2, \mathrm{H}-6$ ), 2.79 ( $\left.\psi \mathrm{t}, 1 \mathrm{H}, \mathrm{J}=12.6,11.4 \mathrm{~Hz}, \mathrm{CH}_{2}, \mathrm{H}-2 \alpha\right), 3.73$ (m, 4H, CH, $\mathrm{H}-3$ "',5"),

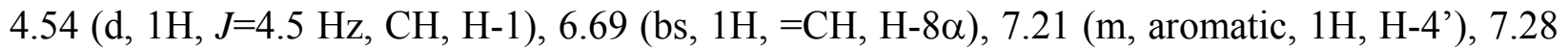
(m, aromatic, $\left.2 \mathrm{H}, \mathrm{H}-2^{\prime}, 6^{\prime}\right), 7.32\left(\mathrm{~m}\right.$, aromatic, $\left.2 \mathrm{H}, \mathrm{H}-3^{\prime}, 5^{\prime}\right) ;{ }^{13} \mathrm{C} \mathrm{NMR}\left(100 \mathrm{MHz}, \mathrm{CDCl}_{3}\right) \delta_{\mathrm{C}}$ :

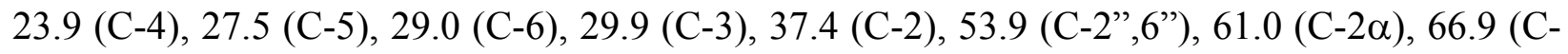

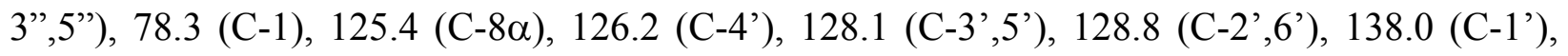
$143.8(\mathrm{C}-8)$.

trans-E-2-Phenylmethylene-7-morpholin-1-ylmethyl-cycloheptanol (17). We were not able to separate this minor isomer. ${ }^{1} \mathrm{H}$ NMR $\left(400 \mathrm{MHz}, \mathrm{CDCl}_{3}\right) \delta_{\mathrm{H}}: 1.13\left(\mathrm{~m}, 1 \mathrm{H}, \mathrm{CH}_{2}, \mathrm{H}-3\right), 1.39$ (m, 1H, $\left.\mathrm{CH}_{2}, \mathrm{H}-3\right), 1.49$ (m, 1H, $\left.\mathrm{CH}_{2}, \mathrm{H}-5\right), 1.51$ (m, 1H, $\left.\mathrm{CH}_{2}, \mathrm{H}-6\right), 1.71$ (m, 1H, CH, $\left.\mathrm{H}-5\right), 1.79$ (m, 1H, CH, H-2), 1.82 (m, 1H, CH $\left.\mathrm{CH}_{2} \mathrm{H}-6\right), 2.37$ (m, 1H, $\left.\mathrm{CH}_{2}, \mathrm{H}-4\right), 2.40$ (m, 2H, CH, $\mathrm{H}-2$ ", 6"), 2.42 (m, 1H, CH, $\mathrm{H}-2 \alpha), 2.43$ (m, 1H, $\left.\mathrm{CH}_{2}, \mathrm{H}-4\right), 2.55$ (m, 1H, $\left.\mathrm{CH}_{2}, \mathrm{H}-2 \alpha\right), 2.67$ (m, 2H, $\mathrm{CH}_{2}$, H-2",6”), 3.70 (m, 4H, CH, H-3",5"), 4.05 (d, 1H, J=8.7 Hz, CH, H-1), 6.67 (bs, 1H, =CH, H$8 \alpha)$, 7.14-7.37 (m, aromatic region, 5H, H-4', H-2',6' and $\mathrm{H}-3$ ', 5'); ${ }^{13} \mathrm{C} \mathrm{NMR} \mathrm{(100} \mathrm{MHz,}$ $\left.\mathrm{CDCl}_{3}\right)$ \&: 26.8 (C-4), 27.0 (C-5), 28.0 (C-6), 28.8 (C-3), 42.0 (C-2), 53.8 (C-2”,6”), 66.6 (C-

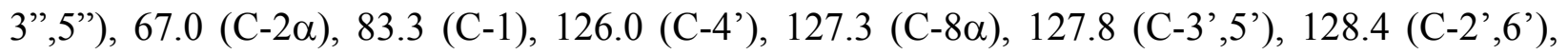
137.7 (C-1'), 143.6 (C-8).

cis-E-2-Phenylmethylene-7-piperidin-1-ylmethyl-cycloheptanol (18). Colorless crystals; yield 72\% for cis-18 and $t r-18 ; \mathrm{mp} 71^{\circ} \mathrm{C}$ (from hexane-ether mixture, dec.). Anal. calcd. for $\mathrm{C}_{20} \mathrm{H}_{29} \mathrm{NO}$ : C, 80.22; H, 9.76; N, 4.68; found: C, 80.14; H, 9.91; N, 4.78. IR (KBr) v $v_{\max }$ : 3170, 
2939, 2925, 2875, 2851, 2776, 1489, 1443, 1129, 1115, 1087, 857 and $698 \mathrm{~cm}^{-1} .{ }^{1} \mathrm{H}$ NMR (400 $\left.\mathrm{MHz}, \mathrm{CDCl}_{3}\right) \delta_{\mathrm{H}}: 1.28\left(\mathrm{~m}, 1 \mathrm{H}, \mathrm{CH}_{2}, \mathrm{H}-3\right), 1.45$ (m, 2H, $\mathrm{CH}_{2}, \mathrm{H}-4$ "), 1.48 (m, 2H, $\left.\mathrm{CH}_{2}, \mathrm{H}-4\right)$, 1.62 (m, 6H, CH $2, \mathrm{H}-3, \mathrm{H}-5$ and H-3",5"), 1.73 (m, 1H, $\left.\mathrm{CH}_{2}, \mathrm{H}-5\right), 2.11$ (dd, 1H, J=12.6, $2.9 \mathrm{~Hz}$, $\left.\mathrm{CH}_{2}, \mathrm{H}-2 \alpha\right), 2.16$ (m, 1H, CH, $\mathrm{H}-6$ ), 2.35 (m, 2H, $\mathrm{CH}_{2}, \mathrm{H}-2$ ", 6"), 2.45 (m, 1H, CH, H-2), 2.64 (m, 2H, $\mathrm{CH}_{2}, \mathrm{H}-2$ ", 6"), 2.70 (m, 1H, $\left.\mathrm{CH}_{2}, \mathrm{H}-6\right), 2.76$ (t, $\left.1 \mathrm{H}, J=12.6 \mathrm{~Hz}, \mathrm{CH}_{2}, \mathrm{H}-2 \alpha\right), 4.53$ (d, $1 \mathrm{H}, J=4.5 \mathrm{~Hz}, \mathrm{CH}, \mathrm{H}-1), 6.70(\mathrm{bs}, 1 \mathrm{H},=\mathrm{CH}, \mathrm{H}-8 \alpha), 7.19(\mathrm{~m}$, aromatic, $1 \mathrm{H}, \mathrm{H}-4$ '), $7.28(\mathrm{~m}$, aromatic, $\left.2 \mathrm{H}, \mathrm{H}-2^{\prime}, 6^{\prime}\right), 7.32\left(\mathrm{~m}\right.$, aromatic, $\left.2 \mathrm{H}, \mathrm{H}-3^{\prime}, 5^{\prime}\right) .{ }^{13} \mathrm{C} \mathrm{NMR}\left(100 \mathrm{MHz}, \mathrm{CDCl}_{3}\right) \delta_{\mathrm{C}}: 23.8$ (C-4), 24.1 (C-4”), 25.9 (C-3",5”), 27.6 (C-5), 29.1 (C-6), 30.1 (C-3), 37.5 (C-2), 54.9 (C-2”,6”),

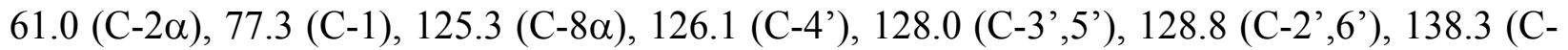
1 '), 143.9 (C-8).

trans-E-2-Phenylmethylene-7-piperidin-1-ylmethyl-cycloheptanol trans-18. Colorless crystals; $\mathrm{mp} 73^{\circ} \mathrm{C}$ (from hexane-ether mixture, dec.). Anal. calcd. for $\mathrm{C}_{20} \mathrm{H}_{29} \mathrm{NO}: \mathrm{C}, 80.22 ; \mathrm{H}$, 9.76; N, 4.68; found: C, 80.11; H, 9.94; N, 4.53. IR (KBr) $v_{\max }$ 3269, 2938, 2923, 2897, 2859, 2781, 1494, 1444, 1122, 1016, 975, 863 and $698 \mathrm{~cm}^{-1} .{ }^{1} \mathrm{H} \mathrm{NMR}\left(400 \mathrm{MHz}, \mathrm{CDCl}_{3}\right) \delta_{\mathrm{H}}: 1.14(\mathrm{~m}$, $\left.1 \mathrm{H}, \mathrm{CH}_{2}, \mathrm{H}-3\right), 1.38$ (m, 1H, CH, $\left.\mathrm{H}-3\right), 1.45$ (m, 3H, $\mathrm{CH}_{2}, \mathrm{H}-4$ and $\mathrm{H}-4$ "), $1.50\left(\mathrm{~m}, 1 \mathrm{H}, \mathrm{CH}_{2}, \mathrm{H}-\right.$ 5), 1.62 (m, 4H, $\mathrm{CH}_{2}, \mathrm{H}-3$ ", 5"), 1.78 (m, $\left.1 \mathrm{H}, \mathrm{CH}_{2}, \mathrm{H}-4\right), 1.80$ (m, $\left.1 \mathrm{H}, \mathrm{CH}, \mathrm{H}-2\right), 1.84(\mathrm{~m}, 1 \mathrm{H}$, $\mathrm{CH}_{2}, \mathrm{H}-5$ ), 2.37 (m, 2H, CH $2, \mathrm{H}-2$ ", 6"), 2.39 (dd, 1H, J=12.6, 3.0 Hz, $\left.\mathrm{CH}_{2}, \mathrm{H}-2 \alpha\right), 2.39$ (m, 1H, $\left.\mathrm{CH}_{2}, \mathrm{H}-6\right), 2.45$ (m, 1H, CH $\left.2, \mathrm{H}-6\right), 2.54$ (t, $\left.1 \mathrm{H}, J=12.6 \mathrm{~Hz}, \mathrm{CH}_{2}, \mathrm{H}-2 \alpha\right), 2.71$ (m, 2H, $\mathrm{CH}_{2}, \mathrm{H}-$

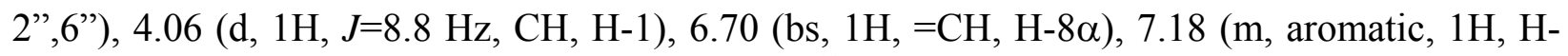
4'), 7.29 (m, aromatic, 4H, H-2',6' and $\left.\mathrm{H}-3^{\prime}, 5^{\prime}\right) ;{ }^{13} \mathrm{C} \mathrm{NMR}\left(100 \mathrm{MHz}, \mathrm{CDCl}_{3}\right) \delta_{\mathrm{C}}: 24.0$ (C-4'), 25.8 (C-3",5"), 27.0 (C-6), 27.3 (C-4), 28.3 (C-5), 29.1 (C-3), 42.5 (C-2), 55.1 (C-2",6”), 67.4

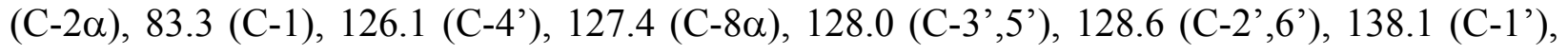
144.1 (C-8).

cis-E-2-Phenylmethylene-8-morpholin-1-ylmethyl-cyclooctanol cis-19. Colorless crystals; yield $90 \% ; \mathrm{mp} 76^{\circ} \mathrm{C}$ (from hexane-ether mixture, dec.). Anal. calcd. for $\mathrm{C}_{20} \mathrm{H}_{29} \mathrm{NO}_{2}: \mathrm{C}, 76.15 ; \mathrm{H}$, 9.27; N, 4.44; found: C, 76.26; H, 9.46; N, 4.31. IR (KBr) $v_{\max }$ : 3168, 2959, 2916, 2877, 2853, 2767, 1451, 1131, 1115, 1009, 974, 866 and $699 \mathrm{~cm}^{-1} .{ }^{1} \mathrm{H}$ NMR $\left(400 \mathrm{MHz}, \mathrm{CDCl}_{3}\right) \delta_{\mathrm{H}}: 1.38(\mathrm{~m}$, 1H, $\left.\mathrm{CH}_{2}, \mathrm{H}-3\right), 1.43$ (m, 1H, $\left.\mathrm{CH}_{2}, \mathrm{H}-5\right), 1.45$ (m, 1H, $\left.\mathrm{CH}_{2}, \mathrm{H}-4\right), 1.48$ (m, 1H, $\left.\mathrm{CH}_{2}, \mathrm{H}-3\right), 1.60$ (m, 1H, $\left.\mathrm{CH}_{2}, \mathrm{H}-5\right), 1.66$ (m, 2H, CH $2, \mathrm{H}-6$ ), 1.69 (m, 1H, $\left.\mathrm{CH}_{2}, \mathrm{H}-4\right), 2.24$ (dd, 1H, J=12.7, 3.3 $\mathrm{Hz}, \mathrm{CH}_{2}, \mathrm{H}-2 \alpha$ ), 2.36 (m, 1H, CH, H-2), 2.44 (m, 2H, $\mathrm{CH}_{2}, \mathrm{H}-2$ ", 6"), 2.54 (m, 2H, $\mathrm{CH}_{2}, \mathrm{H}-7$ ), 2.67 (m, 2H, CH, $\mathrm{H}-2$ ",6"), 2.77 (t, $1 \mathrm{H}, J=12.7 \mathrm{~Hz}, \mathrm{CH}_{2}, \mathrm{H}-2 \alpha$ ), 3.73 (m, 4H, $\mathrm{CH}_{2}, \mathrm{H}-3$ ", 5"), 4.70 (d, 1H, J=3.4 Hz, CH, H-1), 6.63 (bs, $1 \mathrm{H},=\mathrm{CH}, \mathrm{H}-8 \alpha$ ), 7.19 (m, aromatic, $1 \mathrm{H}, \mathrm{H}-4$ '), 7.29 (m, aromatic, 2H, H-2',6'), 7.32 (m., aromatic, $\left.2 \mathrm{H}, \mathrm{H}-3^{\prime}, 5^{\prime}\right) ;{ }^{13} \mathrm{C}$ NMR $\left(100 \mathrm{MHz}, \mathrm{CDCl}_{3}\right) \delta_{\mathrm{C}}$ : 24.7 (C-4), 25.2 (C-6), 27.6 (C-3), 28.7 (C-5), 29.9 (C-7), 38.4 (C-2), 54.1 (C-2",6”), 61.9 (C-

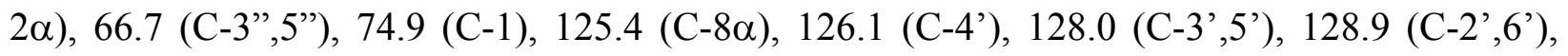
138.1 (C-1'), 143.8 (C-8).

cis-E-2-Phenylmethylene-8-piperidin-1-ylmethyl-cyclooctanol cis-20 Colorless crystals; yield $93 \%$; mp $96^{\circ} \mathrm{C}$ (from hexane-ether mixture, dec.). Anal. calcd. for $\mathrm{C}_{21} \mathrm{H}_{31} \mathrm{NO}$ : $\mathrm{C}, 80.45 ; \mathrm{H}, 9.97$; N, 4.47; found: C, 80.52; H, 10.18; N, 4.50. IR (KBr) $v_{\max }$ : 3140, 2946, 2930, 2921, 2878, 2848 , $1598,1490,1446,1302,1102,1044,974,749$ and $703 \mathrm{~cm}^{-1} .{ }^{1} \mathrm{H}$ NMR $\left(400 \mathrm{MHz}, \mathrm{CDCl}_{3}\right) \delta_{\mathrm{H}}$ : 1.29 (m, 1H, CH $2, \mathrm{H}-3), 1.42$ (m, 1H, CH $2, \mathrm{H}-5), 1.44$ (m, 2H, $\mathrm{CH}_{2}, \mathrm{H}-4$ "), 1.50 (m, 1H, $\mathrm{CH}_{2}, \mathrm{H}-$ 
3), 1.60 (m, 4H, $\mathrm{CH}_{2}, \mathrm{H}-3$ ", 5"), 1.65 (m, 1H, $\left.\mathrm{CH}_{2}, \mathrm{H}-5\right), 1.66$ (m, 2H, $\left.\mathrm{CH}_{2}, \mathrm{H}-4\right), 1.70$ (m, 2H, $\mathrm{CH}_{2}, \mathrm{H}-6$ ), 2.17 (dd, $1 \mathrm{H}, \mathrm{J}=12.8,3.1 \mathrm{~Hz}, \mathrm{CH}_{2}, \mathrm{H}-2 \alpha$ ), 2.33 (m, 2H, $\mathrm{CH}_{2}, \mathrm{H}-2$ ", 6"), 2.39 (m, 1H, $\mathrm{CH}, \mathrm{H}-2), 2.56$ (m, 2H, CH $2, \mathrm{H}-7), 2.61$ (m, 2H, CH $2, \mathrm{H}-2$ ", 6"), 2.72 (dd, 1H, J=12.8, $10.7 \mathrm{~Hz}$, $\left.\mathrm{CH}_{2}, \mathrm{H}-2 \alpha\right), 4.73$ (d, $\left.1 \mathrm{H}, J=3.8 \mathrm{~Hz}, \mathrm{CH}, \mathrm{H}-1\right), 6.65$ (bs, $1 \mathrm{H},=\mathrm{CH}, \mathrm{H}-8 \alpha$ ), 7.19 (m, aromatic, $1 \mathrm{H}$, H-4'), 7.28-7.36 (m, aromatic, 4H, H-2',6'and H-3', ' '); ${ }^{13} \mathrm{C}$ NMR $\left(100 \mathrm{MHz}, \mathrm{CDCl}_{3}\right) \delta_{\mathrm{C}}: 24.2$ (C-4”), 24.4 (C-6), 25.0 (C-4), 26.1 (C-3",5”), 28.1 (C-3), 29.5 (C-5), 30.8 (C-7), 38.9 (C-2),

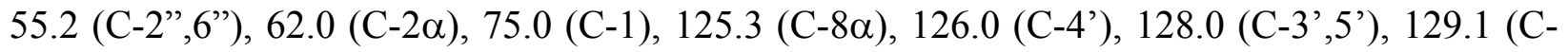
2',6'), 138.5 (C-1'), 144.1 (C-8).

trans-2-Morpholin-4-ylmethyl-indan-1-ol trans-21. Colorless crystals; yield 90\%; mp $68{ }^{\circ} \mathrm{C}$ (from hexane-ether mixture, dec.). Anal. calcd. for $\mathrm{C}_{14} \mathrm{H}_{19} \mathrm{NO}_{2}: \mathrm{C}, 72.06 ; \mathrm{H}, 8.21 ; \mathrm{N}, 6.01$; found: C, 72.21; H, 8.29; N, 5.92. IR (KBr) $v_{\max }$ : 3409, 2954, 2927, 2850, 2817, 1454, 1304, 1264, 1117, 1058, 1005, 867 and $751 \mathrm{~cm}^{-1} .{ }^{1} \mathrm{H} \mathrm{NMR}\left(400 \mathrm{MHz}, \mathrm{CDCl}_{3}\right) \delta_{\mathrm{H}}: 2.46\left(\mathrm{~m}, 2 \mathrm{H}, \mathrm{CH}_{2}\right.$, H-2",6"), 2.48 (m, 1H, CH, $\mathrm{H}-6$ ), 2.52 (m, 1H, CH, H-8), 2.66 (m, 2H, $\mathrm{CH}_{2}, \mathrm{H}-8 \alpha$ ), 2.70 (m, 2H, CH 2 , H-2",6"), 2.95 (m, 1H, $\mathrm{CH}_{2}, \mathrm{H}-6$ ), 3.73 (m, 4H, $\mathrm{CH}_{2}, \mathrm{H}-3$ ", 5"), 5.00 (d, 1H, J=7.5 Hz, $\mathrm{CH}, \mathrm{H}-1), 7.18$ (m, aromatic, $1 \mathrm{H}, \mathrm{H}-3), 7.19$ (m, aromatic, $1 \mathrm{H}, \mathrm{H}-5), 7.22(\mathrm{~m}$, aromatic, $1 \mathrm{H}, \mathrm{H}-$ 4), 7.37 (m, aromatic, $1 \mathrm{H}, \mathrm{H}-2) ;{ }^{13} \mathrm{C}$ NMR $\left(100 \mathrm{MHz}, \mathrm{CDCl}_{3}\right) \delta_{\mathrm{C}}: 33.7$ (C-6), 47.1 (C-8), 54.2

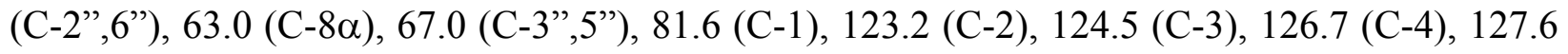
(C-5), 140.8 (C-5a), 144.4 (C-1a).

trans-2-Pyrrolidin-1-ylmethyl-1,2,3,4-tetrahydronaphthalen-1-ol trans-22. Colorless crystals; yield $79 \%$; mp $48{ }^{\circ} \mathrm{C}$ (from hexane-ether mixture, dec.). Anal. calcd. for $\mathrm{C}_{15} \mathrm{H}_{21} \mathrm{NO}$ : C, 77.87; $\mathrm{H}$, 9.16; N, 6.06; found: C, 77.71; H, 9.29; N, 6.28. IR (KBr) $v_{\max }$ : 3180, 2965, 2945, 2871, 2799 , $1464,1345,1136,1040$ and $738 \mathrm{~cm}^{-1} .{ }^{1} \mathrm{H}$ NMR $\left(400 \mathrm{MHz}, \mathrm{CDCl}_{3}\right) \delta_{\mathrm{H}}: 1.44(\mathrm{~m}, 1 \mathrm{H}, J=12.4,5.9$ $\mathrm{Hz}, \mathrm{CH}_{2}, \mathrm{H}-7$ ), 1.72 (m, 1H, CH $2, \mathrm{H}-7$ ), 1.79 (m, 4H, CH, $\mathrm{H}-3$ ", 4"), 1.93 (m, 1H, CH, H-8), 2.48 (dd, 1H, J=12.1, $2.9 \mathrm{~Hz}, \mathrm{CH}_{2}, \mathrm{H}-8 \alpha$ ), 2.52 (m, 2H, CH, $\mathrm{H}-2$ ", 5"), 2.77 (m, 2H, $\mathrm{CH}_{2}, \mathrm{H}-$ 2",5"), 2.81 (m, 1H, $\mathrm{CH}_{2}, \mathrm{H}-6$ ), 2.89 (m, 1H, $\mathrm{CH}_{2}, \mathrm{H}-6$ ), 2.92 (t, 1H, J=12.1 Hz, $\mathrm{CH}_{2}, \mathrm{H}-8 \alpha$ ), 4.67 (d, 1H, J=9.4 Hz, CH, H-1), 7.06 (m, aromatic, 1H, H-5), 7.15 (m, aromatic, $1 \mathrm{H}, \mathrm{H}-4), 7.21$ (m, aromatic, $1 \mathrm{H}, \mathrm{H}-3), 7.60(\mathrm{~m}$, aromatic, $1 \mathrm{H}, \mathrm{H}-2) ;{ }^{13} \mathrm{C}$ NMR $\left(100 \mathrm{MHz}, \mathrm{CDCl}_{3}\right) \delta_{\mathrm{C}}: 23.4(\mathrm{C}-$

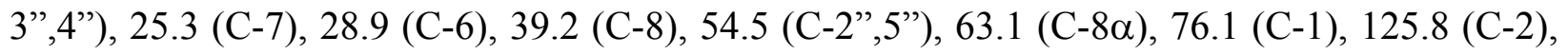
126.1 (C-3), 126.5 (C-4), 128.1 (C-5), 135.1 (C-5a), 139.4 (C-1a).

\section{General procedure for the reductions of 3 with other complex hydrides}

A solution of $3(0.20 \mathrm{~g} .0 .62 \mathrm{mmol})$ in methanol $(20 \mathrm{~mL})$ was treated with aqueous $(10 \mathrm{~mL})$ $\mathrm{Na}_{2} \mathrm{CO}_{3}(0.033 \mathrm{~g}, 0.31 \mathrm{mmol})$ at $0{ }^{\circ} \mathrm{C}$ with stirring. After $2 \mathrm{~min}$ of mixing, ice and water were added and the mixture was extracted with chloroform $(3 \times 25 \mathrm{~mL})$. The chloroform extracts were combined and washed with brine $(2 \times 20 \mathrm{~mL})$ and dried over $\mathrm{Na}_{2} \mathrm{SO}_{4}$ for 1 hour in a refrigerator. The solution was filtered and the solvent was evaporated under reduced pressure. The residue was dissolved in anhydrous ether $(40 \mathrm{~mL})$ and cooled to $0{ }^{\circ} \mathrm{C}$. The reducing agent was added and the mixture was stirred for 5 hours at $0{ }^{\circ} \mathrm{C}$, then for 15 hours at room temperature. The excess of hydride was quenched with methanol at $0{ }^{\circ} \mathrm{C}$, and the mixture was treated with solid $\mathrm{NaOH}$ to decompose the complex. The organic phase was washed first with $10 \% \mathrm{NaOH}(3 \mathrm{x})$, with saturated $\mathrm{NaHCO}_{3}$ solution (3x) and with brine (3x). It was dried over $\mathrm{Na}_{2} \mathrm{SO}_{4}$, filtered, and the 
solvent was evaporated. The residue was subjected to NMR analysis to determine the stereocomposition.

\section{Acknowledgements}

The authors are grateful to the OTKA program (\#T 030261), as well as to the Bolyai and FKFP (Bo/00170/01; 0168/2001) programs for the financial support. We would like to thank Hermann Franz (HASYLAB at DESY) for his help with the beamline during the crystallographic data collection. We wish to thank to Mrs. G. Németh for the technical assistance.

\section{Supplementary Information Available}

X-ray crystallographic data in the form of crystallographic files (CIF) are available.

\section{References}

1. Lóránd, T.; Kocsis, B.; Sohár, P.; Nagy, G.; Kispál, Gy.; Krane, H. G.; Schmitt, H.; Weckert, E. Eur. J. Med. Chem. 2001, 36, 705.

2. Lóránd, T.; Kocsis, B.; Sohár, P.; Nagy, G.; Pál, J.; Kispál, Gy.; László, R.; Prókai, L. Eur. J. Med. Chem. 2002, 37, 803.

3. Lin, A. J.; Cosby, L. A.; Shinshky, C. W.; Sartorelli, A. C. J Med. Chem. 1972, 15, 1247.

4. Taylor, W. G.; Dimmock, J. R. Can. J. Chem. 1974, 52, 2522.

5. Allen, F. H.; Kennard, O.; Watson, D. J.; Brammen, L.; Orpen, A. G.; Taylor, R. In International Tables for X-Ray Crystallography; Wilson, A.J.C., Ed.; Kluwer Academic Publishers: London, 1992; Vol. C.

6. Nikaido, H.; Vaara, M. Microbiol. Rev. 1985, 49, 1.

7. Schnaitman, C. A.; Klena, J. D. Microbiol. Rev. 1993, 57, 655.

8. Raetz, C. R. H.; Whitfield, C. Annu. Rev. Biochem. 2002, 71, 635.

9. Harradence, L. J. Proc. R. Soc. N. S. W. 1938, 72, 284.

10. Kabsch, W. J.Appl.Cryst. 1993, 26, 795.

11. SIR97, Altomare, A.; Cascarano, G.; Giacovazzo, C.; Guagliardi, A.; Moliterni, A. G. G.; BARI, 1997.

12. SHELXL97, Sheldrick, G. M. University of Göttingen, Germany, 1997.

13. Burzlaff, H.; Rothammel, W. 1989 Program 'ATARI CRYSTAN88' Gauglitz, G., Ed.; Proc. $3^{\text {rd }}$ Workshop Computer in der Chemie, Springer: Berlin.

14. Jorgensen, J. H.; Turnidge, J. D.; Washington, J. A. Antibacterial susceptibility tests: dilution and disk diffusion methods In Manual of Clinical Microbiology $7^{\text {th }}$ Edn; Murray, P. R.; Baron, E. J; Pfaller, M. A.; Tenover, F. C.; Yolken, R. H., Eds; ASM: Washington, DC., 1999; pp 1526-1543.

15. Ellman, G. L. Arch. Biochem. Biophys. 1958, 74, 443.

16. Smith, P. K. Anal. Biochem. 1985, 150, 76. 